\title{
Simulating carbon and water cycles of larch forests in East Asia by the BIOME-BGC model with AsiaFlux data
}

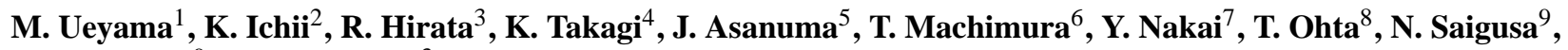 \\ Y. Takahashi ${ }^{9}$, and T. Hirano ${ }^{3}$ \\ ${ }^{1}$ Osaka Prefecture University, Graduate School of Life and Environmental Sciences, 1-1 Gakuen-cho, Naka-ku, Sakai, \\ Osaka, Japan \\ ${ }^{2}$ Fukushima University, Faculty of Symbiotic Systems Science, 1 Kanayagawa, Fukushima, Japan \\ ${ }^{3}$ Hokkaido University, Research Faculty of Agriculture, Kita 9, Nishi 9, Kita-ku, Sapporo, Hokkadio, Japan \\ ${ }^{4}$ Hokkaido University, Field Science Center for Northern Biosphere, Toikanbetu, Horonobe, Hokkadio, Japan \\ ${ }^{5}$ University of Tsukuba, Terrestrial Environment Research Center, 1-1-1 Tennodai, Tsukuba, Ibaraki, Japan \\ ${ }^{6}$ Osaka University, Graduate School of Engineering, 2-1 Yamadaoka, Suita, Osaka, Japan \\ ${ }^{7}$ Forestry and Forest Products Research Institute, 1 Matsunosato, Tsukuba, Japan \\ ${ }^{8}$ Nagoya University, Graduate School of Bioagricultural Sciences, Furo-cho, Chikusa Ward, Nagoya, Aichi, Japan \\ ${ }^{9}$ National Institute for Environmental Studies, Center for Global Environmental Research, 16-2 Onogawa, Tsukuba, \\ Ibaraki, Japan
}

Received: 8 June 2009 - Published in Biogeosciences Discuss.: 24 August 2009

Revised: 11 February 2010 - Accepted: 20 February 2010 - Published: 10 March 2010

\begin{abstract}
Larch forests are widely distributed across many cool-temperate and boreal regions, and they are expected to play an important role in global carbon and water cycles. Model parameterizations for larch forests still contain large uncertainties owing to a lack of validation. In this study, a process-based terrestrial biosphere model, BIOME-BGC, was tested for larch forests at six AsiaFlux sites and used to identify important environmental factors that affect the carbon and water cycles at both temporal and spatial scales.

The model simulation performed with the default deciduous conifer parameters produced results that had large differences from the observed net ecosystem exchange (NEE), gross primary productivity (GPP), ecosystem respiration (RE), and evapotranspiration (ET). Therefore, we adjusted several model parameters in order to reproduce the observed rates of carbon and water cycle processes. This model calibration, performed using the AsiaFlux data, substantially improved the model performance. The simulated annual GPP, RE, NEE, and ET from the calibrated model were highly consistent with observed values.

The observed and simulated GPP and RE across the six sites were positively correlated with the annual mean air tem-
\end{abstract}

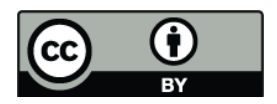

Correspondence to: M. Ueyama (miyabi-flux@muh.biglobe.ne.jp) perature and annual total precipitation. On the other hand, the simulated carbon budget was partly explained by the stand disturbance history in addition to the climate. The sensitivity study indicated that spring warming enhanced the carbon sink, whereas summer warming decreased it across the larch forests. The summer radiation was the most important factor that controlled the carbon fluxes in the temperate site, but the VPD and water conditions were the limiting factors in the boreal sites. One model parameter, the allocation ratio of carbon between belowground and aboveground, was site-specific, and it was negatively correlated with the annual climate of annual mean air temperature and total precipitation. Although this study substantially improved the model performance, the uncertainties that remained in terms of the sensitivity to water conditions should be examined in ongoing and long-term observations.

\section{Introduction}

The northern high latitude region is currently undergoing rapid and drastic warming (IPCC, 2007); the air temperatures in Eastern Siberia have risen by $7^{\circ} \mathrm{C}$ in winter and $1-$ $2{ }^{\circ} \mathrm{C}$ in annual basis during the past few decades (Dolman et al., 2008). The terrestrial ecosystems in this region have responded to the warming climate through various feedback

Published by Copernicus Publications on behalf of the European Geosciences Union. 
processes (Chapin et al., 2005; Hinzman et al., 2005). These changes are likely to affect the carbon and water cycles in boreal and cool temperate forests, altering snow cover, permafrost dynamics, growing season length, and the severity of summer drought.

The predicted climatic changes affect the seasonal weather patterns differently (e.g. Manabe et al., 1992), and it is particularly important to understand how the changes in weather patterns affect terrestrial carbon and water cycles. The effects of current and future climatic changes on the terrestrial carbon and water cycles over northern high-latitude ecosystems are complex. Detected and/or potential effects include: (1) the earlier onset of photosynthetic activity in high-latitude forests due to the spring warming (Myneni et al., 2001; Kimball et al., 2004) leads to greater productivity and thus potentially increases the carbon sink (e.g. Keyser et al., 2000; Euskirchen et al., 2006; Welp et al., 2007); (2) the warming climate potentially stimulates the decomposition of soil carbon (Valentini et al., 2000; Piao et al., 2007; Ueyama et al., 2009) and reduces the carbon sink; and (3) atmospheric drying over the regions of warming could affect the carbon and water cycles of boreal forests since the carbon and water fluxes of boreal forests in Eurasia are highly sensitive to changes in atmospheric humidity (e.g. Schulze et al., 1999; Wang et al., 2005; Ohta et al., 2008).

A number of terrestrial biosphere models have been applied to simulate the carbon and water cycles in high-latitude ecosystems (Euskirchen et al., 2006; Kimball et al., 2007). Although these models were tested with the data observed over the high-latitude biomes (Amthor et al., 2001; Grant et al., 2005), these validations were mostly conducted for evergreen conifer (Cienciala et al., 1998; Clein et al., 2002; Ueyama et al., 2009), deciduous broadleaf (Kimball et al., 1997a), or arctic tundra ecosystems (Engstrom et al., 2006), but rarely conducted for the deciduous conifer (larch) forests. The lack of validation studies for larch forests could induce uncertainties in predicting the high-latitude and global carbon and water cycles.

Larch forests are widely distributed over many cooltemperate and boreal regions in the northern hemisphere (Gower and Richards, 1990). Across Eurasia to East Asia, a number of eddy covariance measurements have been conducted for several larch forests near the arctic (e.g. Ohta et al., 2001; Machimura et al., 2005; Nakai et al., 2008) and over boreal (Wang et al., 2005; Li et al., 2005) and cool temperate (Hirata et al., 2007) regions. These measurements have revealed the important processes that determine the carbon and water cycles in larch forests, such as the environmental factors that control evapotranspiration (Ohta et al., 2008) and carbon flux (Hollinger et al., 1998; Wang et al., 2005; Li et al., 2005; Hirata et al., 2007; Nakai et al., 2008), and the role of stand disturbance (Machimura et al., 2007). Since these analyses are site-specific, we need to analyze them at multiple site scales to clarify how the carbon and water fluxes are spatially distributed, how the responses to the environmental conditions differ spatially, and how terrestrial biosphere models perform in simulating carbon and water dynamics. These studies are limited for larch forest ecosystems because of few observations in comparison, compared with the other forest ecosystems in North America (Baldocchi et al., 2001; Thornton et al., 2002) and Europe (Valentini et al., 2000). However, the recent availability of observations makes it possible to conduct synthesis studies for this ecosystem.

This study is a first step to understand the carbon and water cycles of larch forest in northern Eurasia to East Asia. In this study, a process-based terrestrial biosphere model, BIOMEBGC (Thornton et al., 2002), was tested for larch forests at six AsiaFlux sites and used to identify important environmental factors that affect the carbon and water cycles temporally and spatially. Our specific objectives are to (1) improve the model performance by using the observed flux data; (2) clarify the environmental factors, including climate and stand disturbance, that control the carbon and water fluxes across the larch forests in East Asia; and (3) examine the response of the carbon budget to changes in seasonal weather patterns.

\section{AsiaFlux data}

\subsection{Site descriptions}

The present study is a synthesis of 12 years of site data from six larch forests from Eurasia to East Asia (Fig. 1). The sites include the Tomakomai site (TMK), Japan; the Laoshan site (LSH), China; the Southern Khentii Taiga site (SKT), Mongolia; the Yakutsk site (YLF), Russia; the Neleger site (NEL), Russia; and the Tura site (TUR) in Russia. These sites are part of the AsiaFlux network (Hirata et al., 2008; Saigusa et al., 2008; Mizoguchi et al., 2009), covering a broad range of climate with annual precipitation totals from $240 \mathrm{~mm}$ to $1750 \mathrm{~mm}$ per year and annual mean air temperatures from $-10^{\circ} \mathrm{C}$ to $10^{\circ} \mathrm{C}$. In terms of seasonal climatic variations (Fig. 2), TMK is characterized as a cool temperate climate with a cool early summer, warm winter and spring, and high humidity over the course of the year (low summer VPD and sufficient precipitation). The LSH and SKT sites are characterized by a boreal climate with cold winters, hot summers, dry atmospheric conditions, although LSH has much more precipitation during the summer than SKT. All of the Russian sites (YLF, NEL, and TUR) are characterized by a severe continental climate with cold winters, hot and dry summers, and low precipitation totals. Details of site information are summarized in Table 1.

TMK is a planted Japanese larch (Larix kaempferi) forest located at approximately $15 \mathrm{~km}$ northwest of Tomakomai, Hokkaido, in northern Japan (Hirano et al., 2003; Hirata et al., 2007). The stand was planted in 1957-1959, and the stand age was about 45 years old at the time of this study. The forest was sparsely dominated by broadleaf 


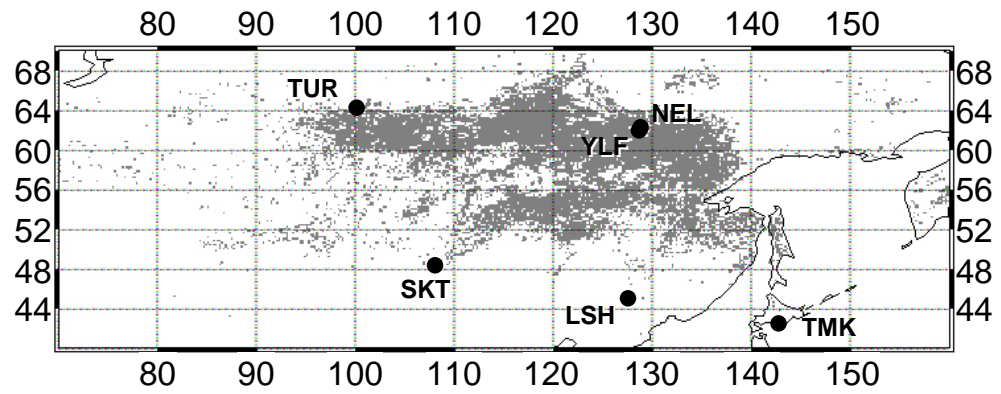

Fig. 1. Location of study sites from northern Eurasia to East Asia. The gray area represents a distribution of larch forest based on the MOD12 landcover classification.

Table 1. Site characteristics.

\begin{tabular}{lcccccccc}
\hline Site & Latitude & Longitude & Elevation $(\mathrm{m})$ & Species & LAI $^{\mathrm{a}}$ & Stand age & Stand height & Year \\
\hline TMK & $42^{\circ} 44^{\prime} \mathrm{N}$ & $141^{\circ} 31^{\prime} \mathrm{E}$ & 140 & Larix kaempferi & $9.2(5.6)$ & 45 & 15 & $2001-2003$ \\
$\mathrm{LSH}$ & $45^{\circ} 20^{\prime} \mathrm{N}$ & $127^{\circ} 34^{\prime} \mathrm{E}$ & 370 & Larix gmelinii & $(2.5)$ & 34 & 17 & 2004 \\
$\mathrm{SKT}$ & $48^{\circ} 21^{\prime} \mathrm{N}$ & $108^{\circ} 39^{\prime} \mathrm{E}$ & 1630 & Larix sibirica & $4.4(2.7)$ & $70 \sim 150$ & 20 & $2003-2005$ \\
$\mathrm{YLF}$ & $62^{\circ} 15^{\prime} \mathrm{N}$ & $129^{\circ} 14^{\prime} \mathrm{E}$ & 220 & Larix cajanderii & $3.7(1.6)$ & 160 & 18 & 2004 \\
$\mathrm{NEL}$ & $62^{\circ} 19^{\prime} \mathrm{N}$ & $129^{\circ} 14^{\prime} \mathrm{E}$ & 200 & Larix cajanderii & $2.9(1.9)$ & $\mathrm{N} / \mathrm{A}$ & 21 & $2003-2005$ \\
TUR & $64^{\circ} 16^{\prime} \mathrm{N}$ & $100^{\circ} 12^{\prime} \mathrm{E}$ & 250 & Larix gmelinii & $(0.3)$ & 105 & 3.4 & 2004 \\
\hline
\end{tabular}

a Total LAI (Larch LAI)

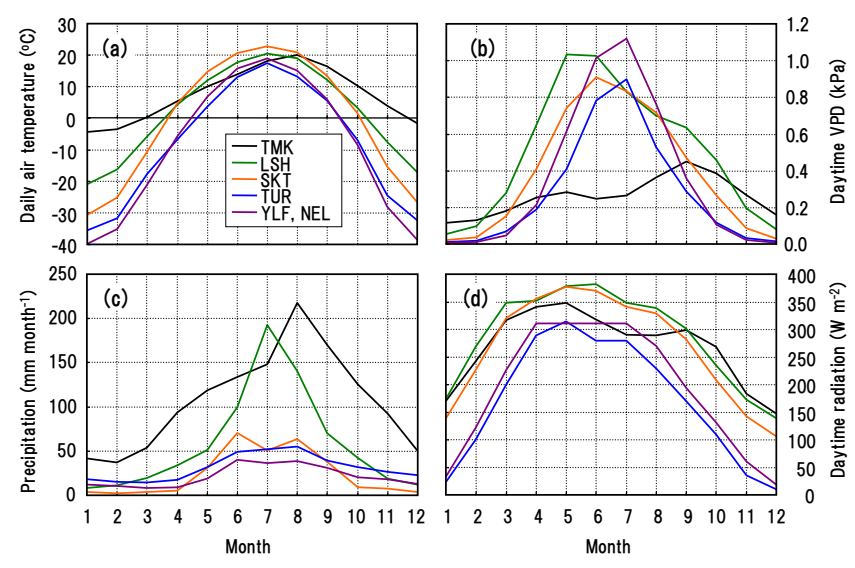

Fig. 2. Seasonal variations of climate variables: (a) air temperature, (b) daytime VPD, (c) precipitation, and (d) daytime solar radiation. The data are derived from weather stations near the site from 1961 to 2000, except that the daytime solar radiation are from the International Satellite Cloud Climatology Project Radiation Flux Profile data (Zhang et al., 2004) from 1984 to 2000. The climate data of TMK are from the Japan Meteorological Agency, and those of other sites are from the National Climate Data Center.

trees (Betula ermanii, Betula platyphylla, and Uhnus japon$i c a$ ) and spruce (Picea jezoensis) with an understory of ferns (Dryopteris crassirhizoma and Dryopteris austriaca). The maximum LAI of larch, other overstory species, and understory species were about $3.1,2.5$, and $3.6 \mathrm{~m}^{2} \mathrm{~m}^{-2}$ in summer, respectively.
LSH is a planted larch (Larix gmelinii) forest in northern China (Wang et al., 2005a, b). The forest was established as a plantation in 1969 as a pure larch forest. The maximum LAI of larch trees was about $2.5 \mathrm{~m}^{2} \mathrm{~m}^{-2}$. Some broadleaf species sparsely consisted of the canopy (e.g. Betula platyphylla, and Fraxinus mandshurica). The forest floor was covered by the understory vegetations, shrubs, and species in the Cyperaceous and Liliaceous families.

SKT is a Siberian larch (Larix sibirica) forest located at approximately $25 \mathrm{~km}$ northeast of the Mongonmorit village in the Tov province of Mongolia ( $\mathrm{Li}$ et al., 2005, 2006, 2007). The age structure of the larch ranged from $\sim 70$ to over 150 years old, but the oldest trees were older than 300 years. The forest experienced a large-scale fire in 1996 1997 in which approximately $37.5 \%$ of the total stem density was burnt. The understory is composed of a distinct layer of grass and scattered shrubs. The maximum LAI of the larch and understory species were about 2.7 and $1.7 \mathrm{~m}^{2} \mathrm{~m}^{-2}$, respectively.

YLF is a Cajander larch (Larix cajanderi) forest located approximately $20 \mathrm{~km}$ north of Yakutsk, Russia, eastern Siberia (Ohta et al., 2001, 2008; Dolman et al., 2004). The larch trees are on permafrost soil with an active layer depth of approximately $1.2 \mathrm{~m}$. The LAI of the larch trees was $1.56 \mathrm{~m}^{2} \mathrm{~m}^{-2}$, whereas the forest floor was covered by a dense understory of vegetation, such as Vaccinium species, with an LAI of $2.1 \mathrm{~m}^{2} \mathrm{~m}^{-2}$. Since there has not been a fire at the site for at least the last 80 years, the average stand age is 160 years. 
NEL is a larch (Larix cajanderi) forest located on the approximately $30 \mathrm{~km}$ northwest of Yakutsk, Russia (Machimura et al., 2005, 2007). The forest is also on continuous permafrost with an active layer depth of approximately $1.0 \mathrm{~m}$. The average tree height was $8.6 \mathrm{~m}$, and the maximum tree height was approximately $21 \mathrm{~m}$. The forest floor was covered by Vaccinium uliginosum and Pyrola incarnate with moss species. The LAI of the larch trees was $1.9 \mathrm{~m}^{2} \mathrm{~m}^{-2}$, whereas that of the understory was $1.0 \mathrm{~m}^{2} \mathrm{~m}^{-2}$.

TUR is a Gmelin larch (Larix gmelinii) forest located in Tura in the Evenkia Autonomous District in Central Siberia (Nakai et al., 2008). The stand age is about 105 years old. The LAI of the larch trees was $\sim 0.3 \mathrm{~m}^{2} \mathrm{~m}^{-2}$. The soil type is Cryosol, and the permafrost table is within $1 \mathrm{~m}$ depth. The forest floor was covered by some shrub species, such as $\mathrm{Be}$ tula nana, Ledum palustre, Vaccinium uliginosum, and Vaccinium vitis-idaea. The ground was densely covered with lichens and mosses.

\subsection{Data processing}

We used the observed carbon and water fluxes from the eddy covariance method for the six tower-sites. The observed net ecosystem exchange (NEE) were partitioned into ecosystem respiration (RE) and gross primary productivity (GPP) using relationships obtained from the nighttime NEE and air temperature (Hirata et al., 2008; Takagi et al., personal communications, 2009). Quality control and gap filling of the data were conducted by standardized methods (Hirata et al., 2008; Takagi et al., personal communications, 2009). Observed half-hourly fluxes and meteorology were aggregated to a daily basis for the model input. In this study, negative and positive NEE values indicate a net sink and source of atmospheric carbon, respectively.

\section{Model}

\subsection{BIOME-BGC model}

The carbon and water cycles of the larch forests were simulated using the BIOME-BGC model (Thornton et al., 2002). The BIOME-BGC is a process-based terrestrial ecosystem model that simulates biogeochemical and hydrologic processes across multiple biomes. The model is driven at a daily time scale with the meteorological values of the daily maximum, minimum, and average air temperatures, precipitation, daytime VPD, and solar radiation.

Evapotranspiration (ET) is estimated from the sum of transpiration, evaporation from the soil and canopy, and sublimation (Kimball et al., 1997b). Evapotranspiration is basically calculated by a Penman-Monteith model (Running and Coughlan, 1988). Soil conductance is simply estimated from the number of days since a rainfall event. Canopy evaporation is estimated from the amount of water intercepted by the canopy. Transpiration is regulated by the canopy conductance under the daily meteorological conditions of the minimum air temperature, VPD, solar radiation, and soil water availability (Jarvis, 1976).

The model has three compartments for carbon and nitrogen: vegetation, litter, and soil. Each compartment is subdivided into four pools on the basis of differences in their function (e.g., leaf, stems, coarse roots, and fine roots) and residence time (e.g., active, intermediate, slow, and passive recycling). GPP is estimated by coupling the Farquhar biochemical model (Farquhar et al., 1980) with a stomatal conductance model (Jarvis, 1976). Ecosystem respiration (RE) is calculated as the sum of autotrophic and heterotrophic respiration (AR and HR, respectively). The AR and HR are calculated from the carbon and nitrogen pools and the temperature (for $\mathrm{AR}$ and $\mathrm{HR}$ ) and soil water condition (for HR only). Further details for the BIOME-BGC model have been described in previous papers (e.g., Kimball et al., 1997a, b; Thornton et al., 2002; Ueyama et al., 2009).

\subsection{Model modifications}

To improve the model performance for the larch forests, we applied three modifications to the original model. The requirement of these modifications were found by checking the default model output with field observations of carbon and water dynamics, seasonal variation in snow cover, and soil temperature. First, we incorporated the seasonality of the percent of leaf nitrogen in Rubisco (PLNR) based on the strong seasonal variation in the leaf $\mathrm{C}: \mathrm{N}$ ratio in larch trees (Kim et al., 2005) and the seasonality of PLNR in deciduous trees (Wilson et al., 2000) as follows:

$$
\begin{aligned}
& \operatorname{PLNR}(d)=\operatorname{PLNR}_{\text {base }} \\
& \operatorname{PLNR}(d)=\operatorname{PLNR}_{\text {base }} \sqrt{\frac{\mathrm{CN}_{\text {leaf }}}{\mathrm{CN}_{\text {litter }}-\left(\mathrm{CN}_{\text {litter }}-\mathrm{CN}_{\text {leaf }}\right) * S}}(d \geq 200) \\
& S=\sin \left(\frac{d-\left(\mathrm{d}_{\text {onset }}+1\right)}{\mathrm{d}_{\text {growth }}+1} \pi\right)
\end{aligned}
$$

where PLNR base is the maximum PLNR (which corresponds to the PLNR of the original BIOME-BGC model); $\mathrm{CN}_{\text {leaf }}$ is the leaf $\mathrm{C}: \mathrm{N}$ ratio; $\mathrm{CN}_{\text {litter }}$ is the litter $\mathrm{C}: \mathrm{N}$ ratio; $d$ is the day of the year; $d_{\text {onset }}$ is the onset day; and $d_{\text {growth }}$ is the length of the growing period. The onset day and growing season length are calculated by the BIOME-BGC model based on an empirical phenology model (White et al., 1997). The incorporation of this seasonality produces a higher GPP in the beginning of the growing season and then a gradual decline of GPP later in the growing season, results which are consistent with flux tower-based GPP measurements (Hirata et al., 2007).

Second, the original BIOME-BGC model substantially overestimated the snow sublimation, which induced an unreasonable snow disappearance in late winter and thus a water deficit in the boreal summer and autumn. We simply modeled the snow disappearance by using only the daily air 
Table 2. Parameters used in the BIOME-BGC model.

\begin{tabular}{|c|c|c|}
\hline Parameter & Original & Improved \\
\hline annual leaf and fine root turnover fraction $\left(\mathrm{yr}^{-1}\right)$ & 1.00 & \\
\hline annual live wood turnover fraction $\left(\mathrm{yr}^{-1}\right)$ & 0.70 & \\
\hline annual whole-plant mortality fraction $\left(\mathrm{yr}^{-1}\right)$ & 0.005 & \\
\hline annual fire mortality fraction $\left(\mathrm{yr}^{-1}\right)$ & 0.005 & \\
\hline new fine root $C$ : new leaf $C$ & 1.4 & $---{ }^{a}$ \\
\hline new stem $C$ : new leaf $C$ & 2.2 & $0.31^{\mathrm{b}}$ \\
\hline new live wood $C$ : new total wood $C$ & 0.071 & \\
\hline new coarse root $C:$ new stem $C$ & 0.29 & $0.56^{\mathrm{b}}$ \\
\hline current growth proportion & 0.5 & \\
\hline 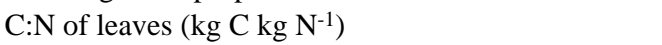 & 27 & \\
\hline 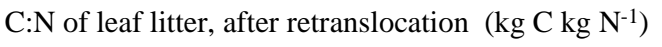 & 120 & \\
\hline $\mathrm{C}: \mathrm{N}$ of fine roots $\left({\left.\mathrm{kg} \mathrm{C} \mathrm{kg} \mathrm{N}^{-1}\right)}\right.$ & 58 & \\
\hline C:N of live wood (kg C kg N-1) & 50 & \\
\hline 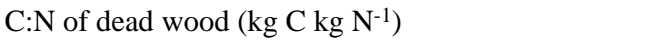 & 730 & \\
\hline leaf litter labile proportion & 0.31 & \\
\hline leaf litter cellulose proportion & 0.45 & \\
\hline leaf litter lignin proportion & 0.24 & \\
\hline fine root labile proportion & 0.34 & \\
\hline fine root cellulose proportion & 0.44 & \\
\hline fine root lignin proportion & 0.22 & \\
\hline dead wood lignin / cellulose proportion & $0.29 / 0.71$ & \\
\hline canopy water interception coefficient $\left(\mathrm{LAI}^{-1} \mathrm{~d}^{-1}\right)$ & 0.045 & $0.045(0.005)^{\mathrm{c}}$ \\
\hline canopy light extinction coefficient $\left(\mathrm{m}^{2} \mathrm{~kg} \mathrm{C}^{-1}\right)$ & 0.51 & \\
\hline all-sided to projected leaf area ratio & 2.6 & \\
\hline canopy average specific leaf area & 22.0 & $16.0^{\mathrm{d}}$ \\
\hline ratio of shaded SLA:sunlit SLA* & 2.0 & \\
\hline fraction of leaf $\mathrm{N}$ in Rubisco & 0.088 & $0.050^{\mathrm{e}}$ \\
\hline maximum stomatal conductance $\left(\mathrm{m} \mathrm{s}^{-1}\right)$ & 0.006 & $0.003^{f}$ \\
\hline cuticular conductance $\left(\mathrm{m} \mathrm{s}^{-1}\right)$ & 0.00006 & \\
\hline boundary layer conductance $\left(\mathrm{m} \mathrm{s}^{-1}\right)$ & 0.09 & \\
\hline PSI*: start of conductance reduction (MPa) & -0.63 & $-0.70^{\mathrm{g}}$ \\
\hline PSI*: complete conductance reduction (MPa) & -2.30 & $-2.60^{\mathrm{g}}$ \\
\hline VPD: start of conductance reduction $(\mathrm{Pa})$ & 610 & $800 \mathrm{~g}$ \\
\hline VPD: complete conductance reduction $(\mathrm{Pa})$ & 3100 & $3200^{\mathrm{g}}$ \\
\hline
\end{tabular}

* PSI, leaf and soil water potential

* SLA, specific leaf area

a Determined each site.

b Kajimoto et al. (1999)

c 0.045 for the sites of TMK, SKT, YLF, NEL, and TUR, whereas 0.005 for LSH.

${ }^{\mathrm{d}}$ Matyssek and Schulze (1987)

e Turner et al. (2003)

$\mathrm{f}$ ranged in previous examined values: Pietsch et al. (1991), and Vygodskaya et al. (1997)

g Pietsch et al. (1991)

temperature in order to make the model reproduce the observed variations of water and carbon fluxes.

Third, we used the monthly moving average for the estimation of soil temperature for further reproduction of the observed results, although the original BIOME-BGC model estimated the soil temperature by using the 10-day moving average of the daily air temperature. The estimated soil tem- perature during the snow period was also overestimated in the TMK site by the original BIOME-BGC model; this was probably caused by the overestimation of the snow insulation effect probably because the difference in snow depth, snow density, and soil porosity among the sites. We changed the parameter for the insulation effect from 0.83 to 0.55 at the simulations of TMK to reproduce the observed soil 
Table 3. Climate biases applied into the sensitivity study. The bias for each season was determined as three times the standard deviation of the natural variability from the long-term climate data shown in Fig. 2.

\begin{tabular}{|c|c|c|c|c|c|c|}
\hline & & TMK & LSH & SKT & YLF & TUR \\
\hline \multirow[t]{4}{*}{ Air Temperature $\left({ }^{\circ} \mathrm{C}\right)$} & spring & 2.8 & 3.7 & 6.0 & 5.1 & 6.0 \\
\hline & summer & 2.9 & 2.1 & 5.1 & 3.0 & 3.4 \\
\hline & autumn & 2.2 & 2.8 & 5.2 & 5.3 & 6.9 \\
\hline & winter & 3.2 & 5.1 & 7.7 & 8.1 & 10.2 \\
\hline \multirow{4}{*}{ Precipitation $(\%)$} & spring & 53 & 54 & 54 & 59 & 61 \\
\hline & summer & 53 & 39 & 47 & 57 & 57 \\
\hline & autumn & 62 & 53 & 42 & 53 & 57 \\
\hline & winter & 57 & 63 & 82 & 60 & 55 \\
\hline \multirow[t]{4}{*}{ VPD (\%) } & spring & 58 & 41 & 43 & 43 & 42 \\
\hline & summer & 54 & 45 & 49 & 39 & 46 \\
\hline & autumn & 22 & 38 & 44 & 39 & 48 \\
\hline & winter & 40 & 69 & 38 & 69 & 33 \\
\hline \multirow[t]{4}{*}{ Solar Radiation (\%) } & spring & 13 & 7 & 6 & 6 & 8 \\
\hline & summer & 22 & 10 & 7 & 8 & 9 \\
\hline & autumn & 14 & 8 & 18 & 15 & 20 \\
\hline & winter & 19 & 6 & 30 & 24 & 41 \\
\hline
\end{tabular}

temperature. This calibration decreased the soil temperature during the snow period and thus decreased the root respiration and $\mathrm{HR}$ in the winter.

\subsection{Model initializations}

The model was initialized by a spinup run, in which the dynamic equilibriums of the soil organic matter and vegetation components were determined by using a constant $\mathrm{CO}_{2}$ concentration of $296 \mathrm{ppm}$ and the observed daily meteorological data and eco-physiological parameters (Table 2). We used soil texture data (Zobler, 1986) and rooting depth data (Webb et al., 1993) as the model inputs for the sites where site-specific observation is not available. Only for the YLF, NEL and TUR sites, we used the observed seasonal maximum of the active layer depth as effective rooting depth. Using the spinup-endpoint as an initial condition, we conducted the model simulations from 1915 to the final year of the observations with the ambient $\mathrm{CO}_{2}$ concentration (Enting et al., 1994; Tans and Conway, 2005). In these simulations, we repeatedly used the observed meteorology at the site rather than the long-term meteorological records from the weather stations near the sites in order to avoid biases due to data discontinuities. Since the observations at YLF, NEL, and TUR were only conducted during periods of the vegetation growth, we used the meteorological data of the National Climate Data Center (NCDC; Global Surface Summary of Day version 8) from weather stations near the sites for the model input for those winter periods.

We implemented simple disturbance treatments for TMK and LSH as plantation and SKT as fire based on the definitions presented by Thornton et al. (2002). For the plantation disturbance of TMK and LSH, we assumed that the amount of vegetation planted was $30 \%$ of the dynamic equilibrium of the vegetation, and the rest was removed from the sites; the leaf and fine root $\mathrm{C}$ and $\mathrm{N}$ pools were included in the fine litter pool. The aboveground live and dead wood $\mathrm{C}$ and $\mathrm{N}$ pools were removed from the site, and the belowground live and dead wood $\mathrm{C}$ and $\mathrm{N}$ pools were included in the coarse woody debris (CWD) pools (Thornton et al., 2002). Based on the stand history (Hirano et al., 2003; Wang et al., 2005a), we assumed that the plantations were established in 1959 for TMK and in 1969 for LSH. Since the stands experienced a large-scale fire in 1996 and 1997 at SKT (Li et al., 2005), we also implemented a fire disturbance in which $37.5 \%$ of the forest was affected. The proportions of the leaf, fine root, live wood, and fine litter $\mathrm{C}$ and $\mathrm{N}$ pools were assumed to be consumed in the fire and lost to the atmosphere, and the affected portions of the dead wood $\mathrm{C}$ and $\mathrm{N}$ pools were sent to the CWD pools (Thornton et al., 2002). Although the stand disturbance history of the mature forest sites in YLF, NEL, and TUR were not available, we inserted a fire disturbance just after the spinup run (year of 1915) for YLF, NEL, and TUR, assuming that the same amount as in SKT, 37.5\%, was affected by the ground fire based on the fact that Siberian larch forests experience a ground fire every 20-50 years (Schulze et al., 1999).

\subsection{Model applications}

We first simulated the carbon and water fluxes by using the original BIOME-BGC model with the original parameters for deciduous needle leaf forest (DNF) shown in Table 2 (White et al., 2000). Then, we calibrated the modified 

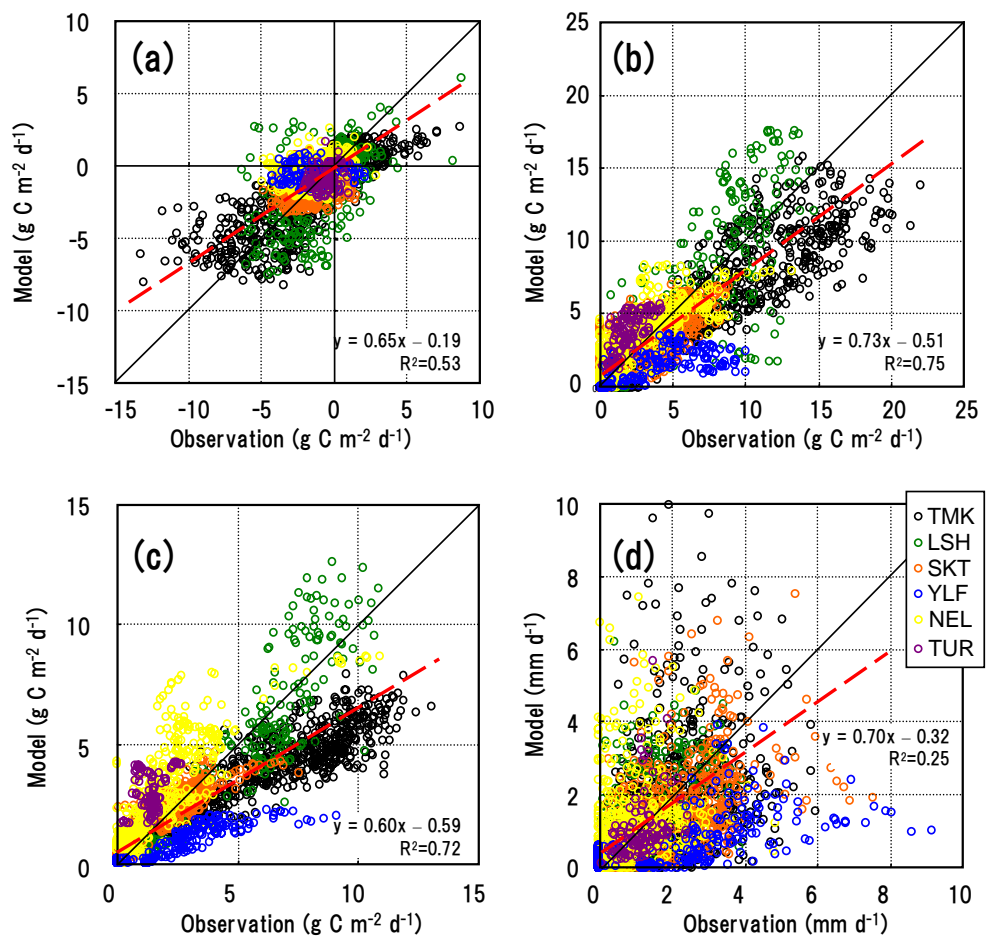

Fig. 3. Observed and modeled (original BIOME-BGC) daily (a) NEE, (b) GPP, (c) RE, and (d) ET. Solid and dashed lines represent the 1:1 and regression lines, respectively.
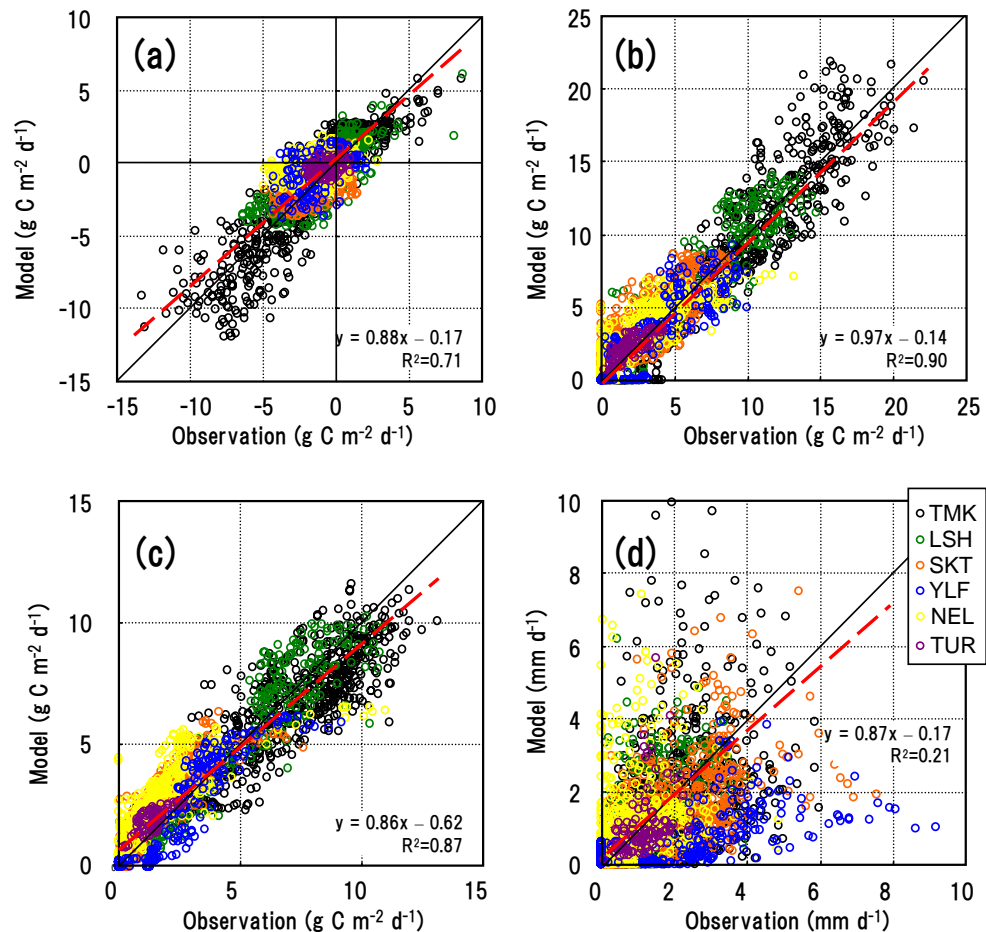

Fig. 4. Observed and modeled (improved BIOME-BGC) daily (a) NEE, (b) GPP, (c) RE, and (d) ET. Solid and dashed lines represent the $1: 1$ and regression lines, respectively. 

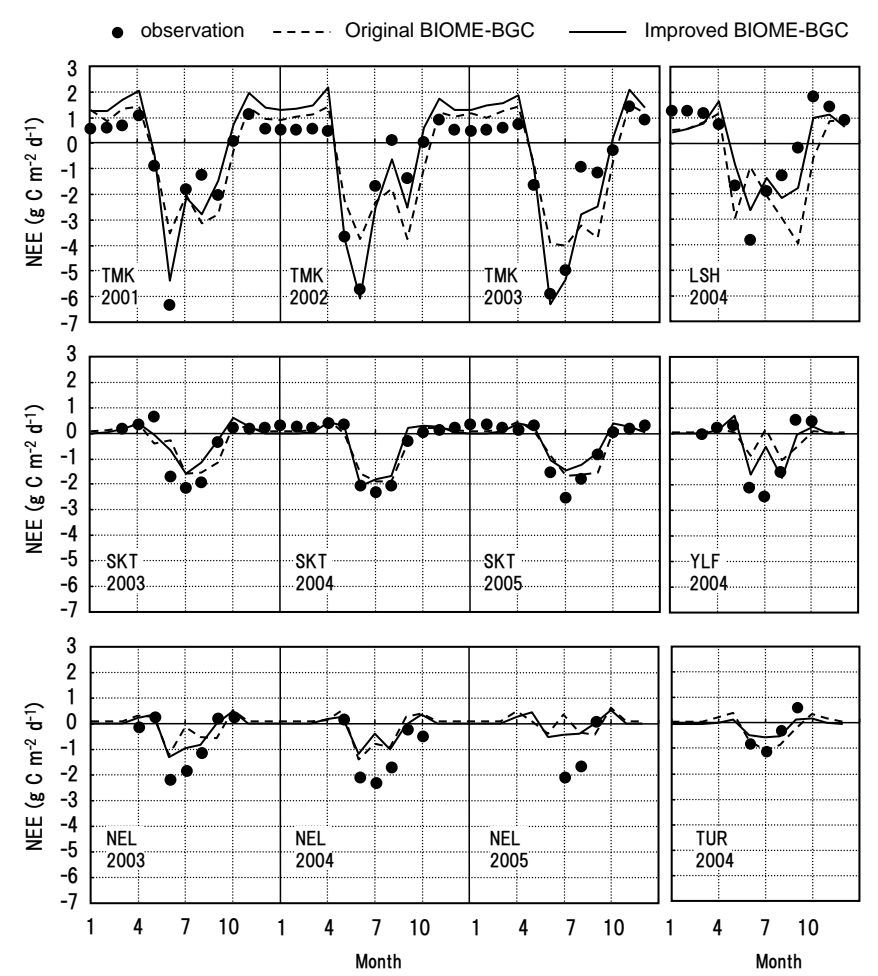

Fig. 5a. Monthly variations of observed (black dots) and simulated (solid lines for the improved model and dashed lines for the original model) (a) NEE, (b) GPP, (c) RE, and (d) ET.
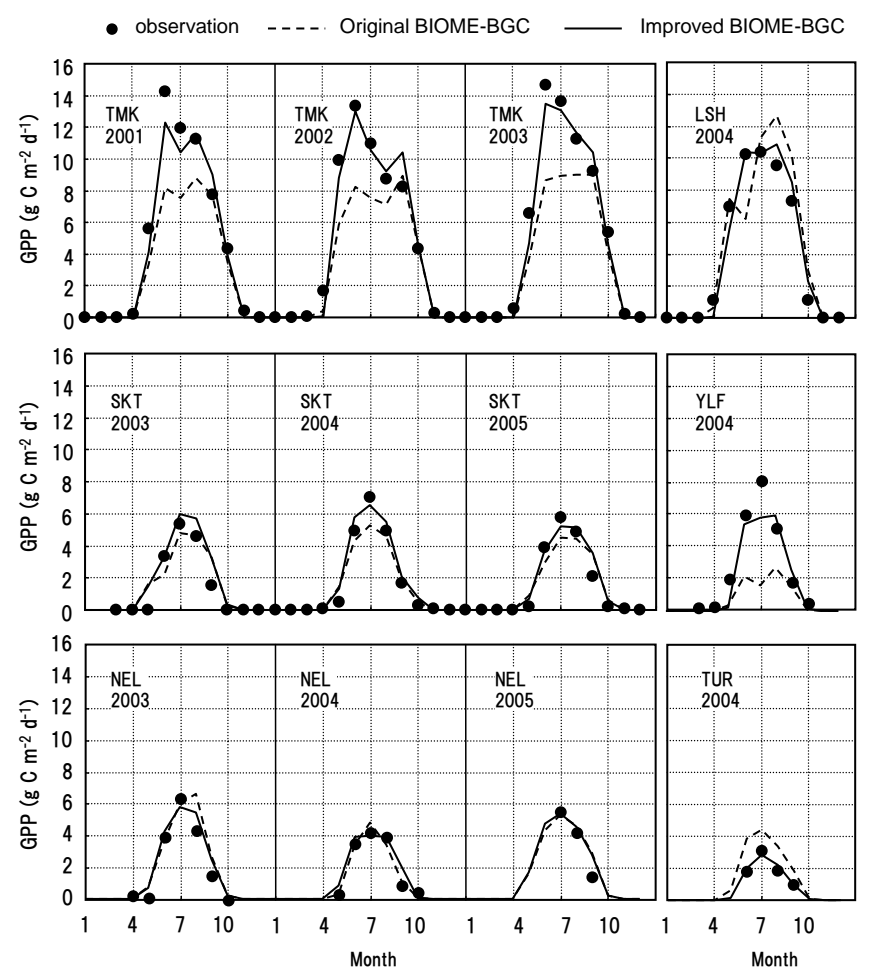

Fig. 5b. GPP. 

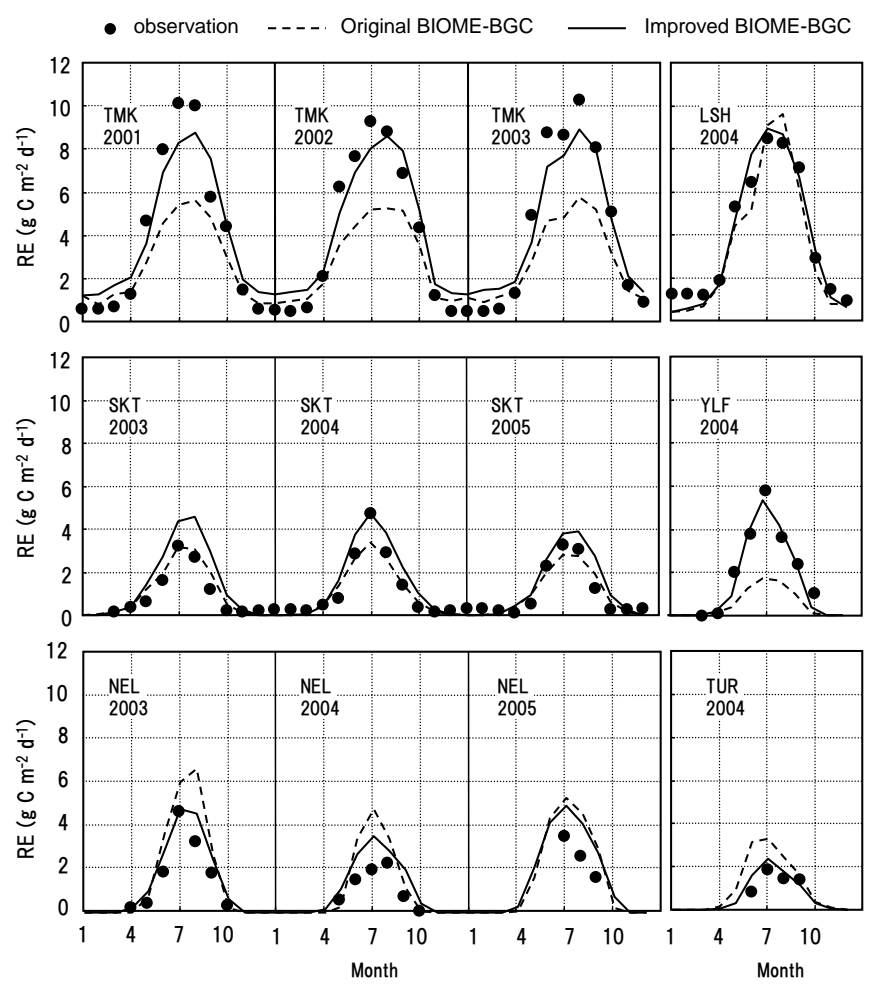

Fig. 5c. RE.
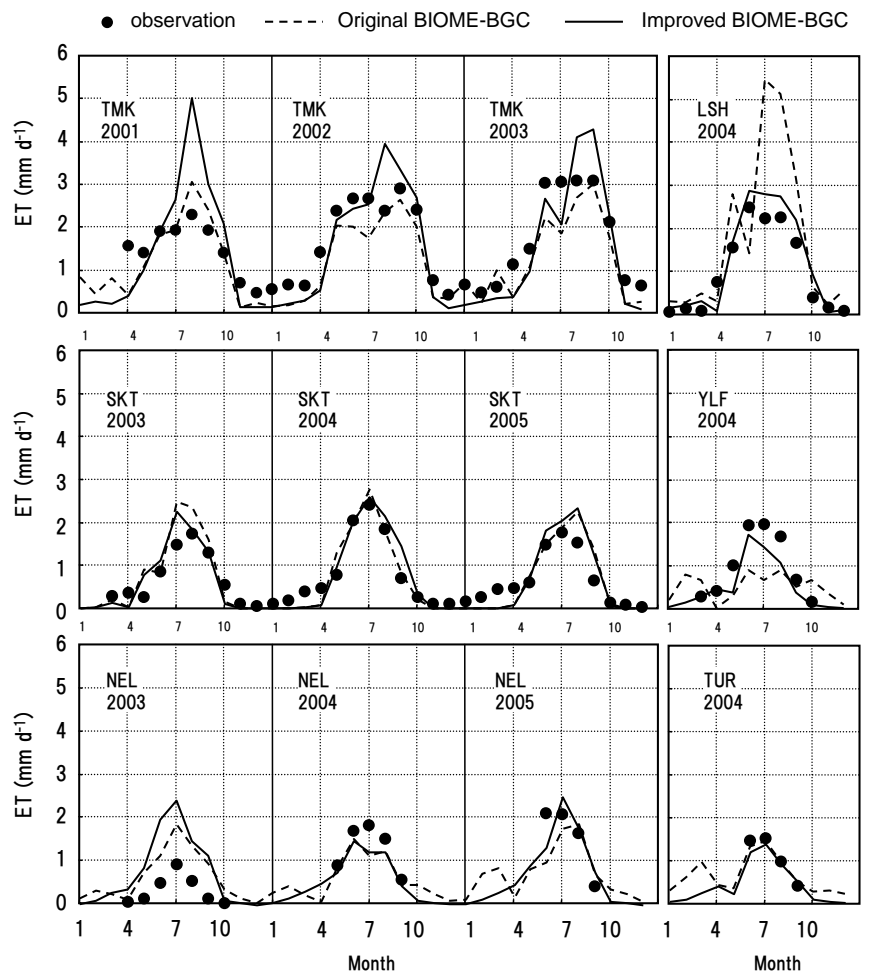

Fig. 5d. ET. 

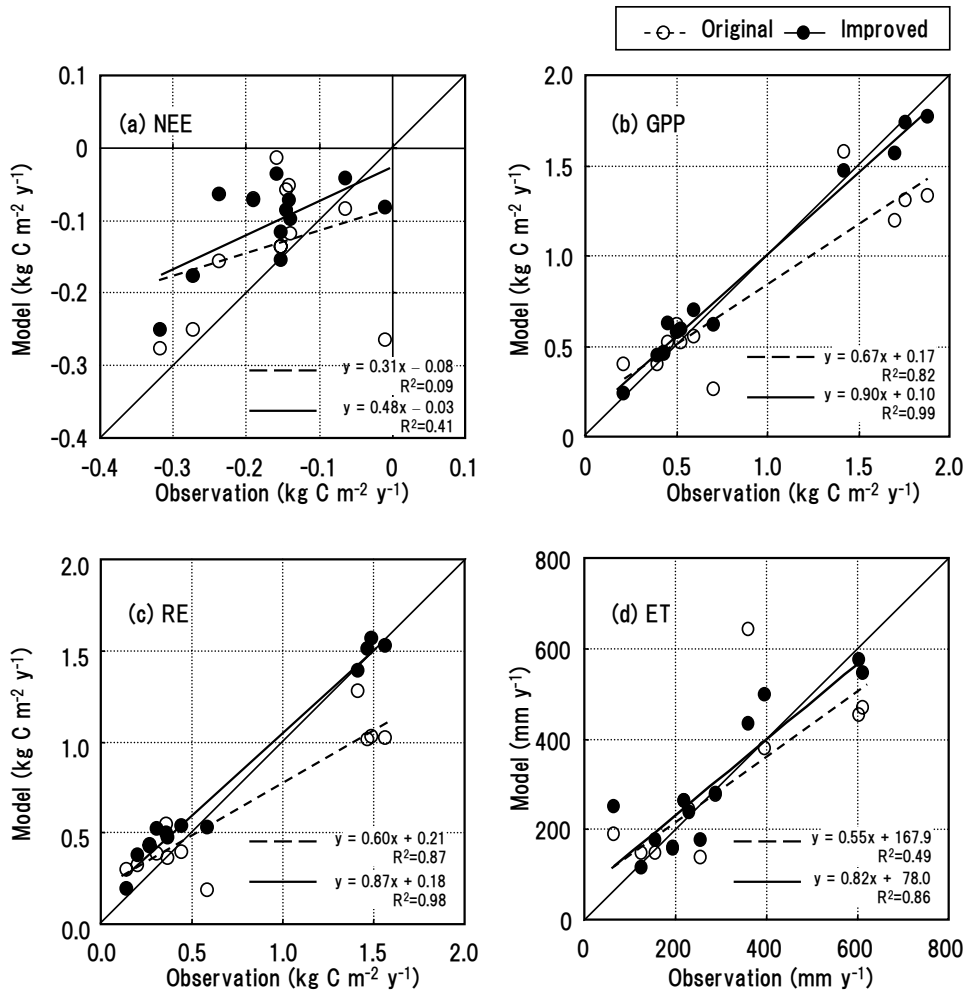

Fig. 6. Observed and modeled (white dots for the original model and black dots for the improved model) (a) NEE, (b) GPP, (c) RE, and (d) ET at an annual time scale. Regression lines (dashed line for the original model and solid line for the improved model) are also shown.

model by using the AsiaFlux data observed at the six larch forests, and evaluated how the AsiaFlux data could improve the model performance for the larch forests in East Asia. Most of the default ecophysiological parameters for DNF are from those for evergreen needleleaf forest (White et al., 2000) owing to limitation of data availability. We updated the new general parameters for DNF in Table 2, referring the literature available data; all of parameters were common across the six sites except for the two site-specific parameters. The model was parameterized according to the following criteria: (1) the parameters were at first changed at a minimum in order to reduce biases in the fluxes, such as the magnitude of day-to-day variations and unrealistic declines due to suppression effects, by referring to the previous studies; and (2) the peak of GPP was adjusted by changing the allocation ratio between new fine roots $\mathrm{C}$ to new leaf $\mathrm{C}\left(\mathrm{A}_{\text {root_leaf }}\right)$. Assuming that the allocation ratio between aboveground and belowground components strongly depends on the climatic conditions (e.g., Friedlingstein et al., 1999; Chapin et al., 2002; Vogel et al., 2008), the parameter for $A_{\text {root_leaf }}$ was determined for each site. The canopy interception coefficient in LSH was only changed to $0.005 \mathrm{LAI}^{-1} \mathrm{~d}^{-1}$ in order to reproduce the observed ET. In both the original and the improved simulation, we applied the stand disturbance treatment in the model initialization (as described in Sect. 3.3). To understand the role of stand disturbance on the annual carbon budget, the observed annual carbon budgets were also compared to the simulated results with and without the stand disturbances.

Next, the spatial distributions of the modeled carbon fluxes were examined by using the annual climatology of each site. The simulated annual values of carbon fluxes from the improved model were compared with the annual climatology of air temperature, precipitation, and radiation to clarify the important climatic variables for determining the spatial variations in the fluxes.

Then, to understand the response of the carbon cycle to changes in the weather conditions, we conducted a sensitivity analysis with biased meteorological data, by giving either warmer or cooler, wetter or drier, and sunnier or cloudier biases for each season; winter (December to February), spring (March to May), summer (June to August), and autumn (September to November). The biases were determined as $3 \sigma$ ( $\sigma$ is the standard deviation) of the long-term natural climate variabilities (Table 3 ). The natural climate variabilities for air temperature, precipitation, and VPD in TMK were estimated by using the weather station data observed by the Japan Meteorological Agency (JMA) from 1961 to 2000, whereas those in LSH, SKT, YLF, NEL, and TUR were estimated from the observations from NCDC from 1981 to 2000. The variabilities for radiation were derived from the International Satellite Cloud Climatology Project Radiation Flux Profile data from 1984 to 2000 (ISCCP-FD; Zhang et al., 2004) centered on the observed site. 


\section{Results and discussion}

\subsection{Model validation}

The original model generally underestimated carbon flux variations at daily, monthly, and annual time scales (Figs. 3, 5 and 6). At the daily time scale, the results were not consistent with the observed fluxes. They showed considerable scatter and underestimated or overestimated the observed values in each site (Fig. 3). The slopes between the observations and the simulation results were 0.65 for NEE, 0.73 for GPP, 0.60 for RE, and 0.70 for ET, which all deviated substantially from 1.0 , and those of $R^{2}$ were $0.53,0.75,0.72$, and 0.25 , respectively. The monthly variations of the simulated and observed fluxes also showed that the amplitude of the flux variation simulated by the original model was inconsistent with the observed results (Fig. 5). The peaks of GPP and RE were generally underestimated for TMK, SKT, and YLF and overestimated for NEL and TUR, although the seasonality, such as the onset and offset of the growing season, was generally reproduced. The annual GPP, RE, and ET were underestimated in TMK, but overestimated in other sites, resulting in those slopes of regression lines that deviated from 1.0 (Fig. 6).

Using the observed fluxes as calibration data, the improved model successfully simulated the carbon and water fluxes at daily, monthly, and annual time scales (Figs. 4, 5 and 6). The seasonality of the carbon fluxes was also substantially improved (Fig. 5). Although the observed peak of GPP and NEE in the TMK site in June could not be reproduced by the original model, the improved model successfully reproduced the phase and amplitude of the carbon fluxes owing to the incorporation of the seasonality of PLNR, which was consistent with the observed results at the leaf (Kim et al., 2005) and canopy scales (Hirata et al., 2007). This improvement suggested that using a constant nitrogen ratio in the leaf could contribute to the uncertainty in the original BIOMEBGC model. In the boreal sites of YLF, NEL, and TUR, since the snow sublimation was reduced due to the modification, the water conserved during the winter was used in the summer periods in the improved model and thus mitigated the water stress (Fig. 5d), resulting in the improvement in an seasonality of ET for YLF. Although the carbon fluxes were substantially improved in the model, the simulated ET at the daily time scale was not substantially improved, compared with the carbon fluxes. This discrepancy might be caused by both the observation and simulation (shown in Sect. 4.4).

The improvements of the model reduced the root mean square error (RMSE) at almost every site (Table 4), and the slops became closer to 1.0 (Figs. 4 and 6). The results from the improved model simulation highly correlated with the observed GPP $\left(R^{2}=0.99\right), \operatorname{RE}\left(R^{2}=0.98\right)$, and ET $\left(R^{2}=0.86\right)$, compared to the results from the original simulation (Fig. 6). The annual carbon budget simulated by the model was also improved by the calibrations. On the other
Table 4. Root mean square error (RMSE) between observed and simulated carbon and water fluxes at a daily time scale.

\begin{tabular}{|c|c|c|c|c|c|}
\hline & & $\begin{array}{c}\mathrm{NEE} \\
\mathrm{gC} \mathrm{m}^{-2} \mathrm{~d}^{-1}\end{array}$ & $\begin{array}{c}\mathrm{GPP} \\
\mathrm{g} \mathrm{C} \mathrm{m}^{-2} \mathrm{~d}^{-1}\end{array}$ & $\begin{array}{c}\mathrm{RE} \\
\mathrm{gC} \mathrm{m}^{-2} \mathrm{~d}^{-1}\end{array}$ & $\begin{array}{c}\mathrm{ET} \\
\mathrm{mm} \mathrm{d}^{-1}\end{array}$ \\
\hline \multirow[t]{2}{*}{ TMK } & original & 1.6 & 2.6 & 2.4 & 2.0 \\
\hline & improved & 1.4 & 1.5 & 1.2 & 3.0 \\
\hline \multirow[t]{2}{*}{ LSH } & original & 2.2 & 2.5 & 1.3 & 2.1 \\
\hline & improved & 1.3 & 1.3 & 1.0 & 1.0 \\
\hline \multirow[t]{2}{*}{ SKT } & original & 0.9 & 1.1 & 0.5 & 0.8 \\
\hline & improved & 0.9 & 1.1 & 0.8 & 0.8 \\
\hline \multirow[t]{2}{*}{ YLF } & original & 1.5 & 3.2 & 1.9 & 1.0 \\
\hline & improved & 1.3 & 1.5 & 0.7 & 0.7 \\
\hline \multirow[t]{2}{*}{ NEL } & original & 1.6 & 1.6 & 1.6 & 1.4 \\
\hline & improved & 1.4 & 1.5 & 1.5 & 1.6 \\
\hline \multirow[t]{2}{*}{ TUR } & original & 0.9 & 2.0 & 1.6 & 0.9 \\
\hline & improved & 0.7 & 0.7 & 0.6 & 0.9 \\
\hline \multirow[t]{2}{*}{ average } & original & 1.4 & 2.2 & 1.6 & 1.4 \\
\hline & improved & 1.2 & 1.3 & 0.9 & 1.3 \\
\hline
\end{tabular}

hand, the improved model still only explained $41 \%$ of the variation in the observed NEE carbon budget (Fig. 6a); the simulated results by the improved model had a tendency to underestimate the observed carbon uptake.

The inclusion of the stand history was an important factor for improving annual NEE estimation (Fig. 7). If we run the model without including stand history, the simulated NEE was substantially underestimated in both the original and improved models. The simulations run without including the stand history could not reproduce the observed annual NEE $\left(R^{2}=0.13\right)$, whereas those considering the stand history reproduced $50 \%$ of the variation. The model performance for estimation of the annual NEE was improved by considering the stand history; the annual sink was increased in the planted sites of TMK and LSH and the fire-disturbed site of SKT by considering the stand histories.

Overall, the model was successfully improved by the calibration with regional network of flux tower measurements. The improved model reasonably reproduced the carbon and water fluxes at the daily, monthly, and annual time scales, although the daily water flux still had uncertainties. We used this improved model to evaluate the spatial distributions of the fluxes and the sensitivity of the fluxes to the weather conditions.

\subsection{Spatial gradient of carbon cycle and climate}

The sensitivities of the simulated annual carbon and water fluxes to the annual climate are shown in Fig. 8. Across the six sites, the simulated GPP and RE substantially increased with the annual air temperature $\left(R^{2}=0.84 ; p<0.01\right.$ for GPP and $R^{2}=0.82 ; p<0.01$ for RE) as well as the annual precipitation $\left(R^{2}=0.86 ; p<0.01\right.$ for GPP and $R^{2}=0.85$; $p<0.01$ for RE), and there was no clear relationship between those fluxes and the amount of radiation $\left(R^{2}=0.20\right.$; $p=0.38$ for GPP and $R^{2}=0.16 ; p=0.38$ for RE). Since 

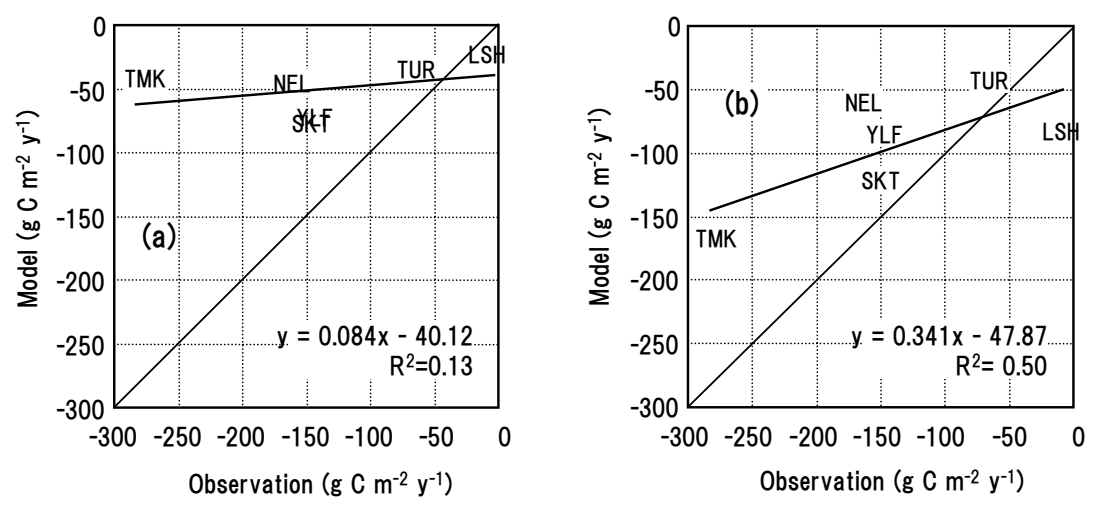

Fig. 7. Observed and simulated annual NEE (a) without and (b) with stand history. The annual values were only calculated during the period when observed data were available.
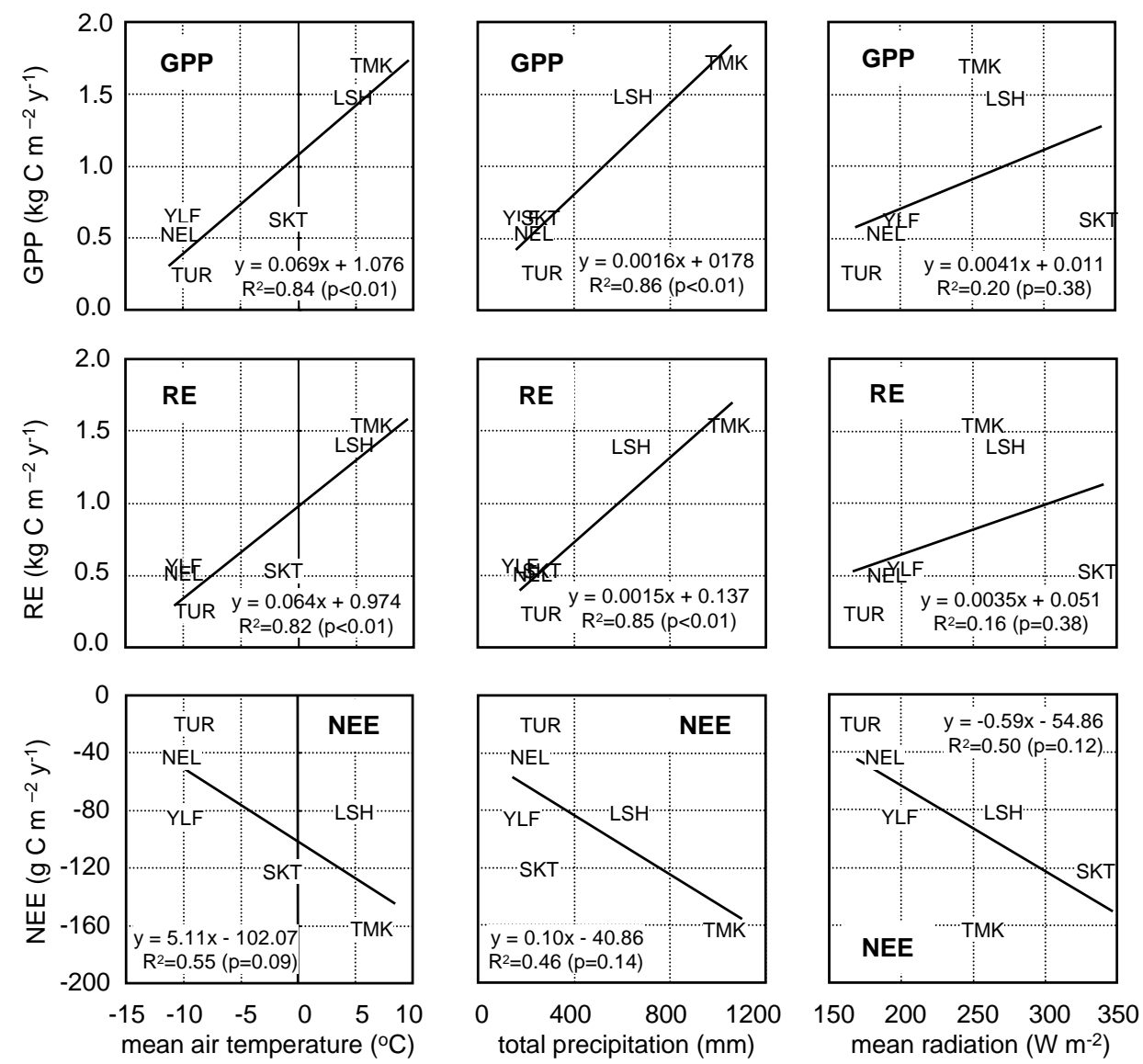

Fig. 8. Relationships between mean annual climate variables (air temperature, precipitation, and radiation) and simulated annual GPP, RE, and NEE. Symbols are as in Table 1.

there was a strong correlation between annual air temperature and precipitation across the sites, we could not identify which of these processes was the more important controlling factor for explaining the spatial variation of those fluxes. Since the simulated annual fluxes were consistent with the observed results (Fig. 6), these trends were also applicable to the observed fluxes. Our results indicated that the air temperature and/or precipitation are potentially important controlling factors for explaining the spatial distribution of the carbon and water fluxes of larch forests. 

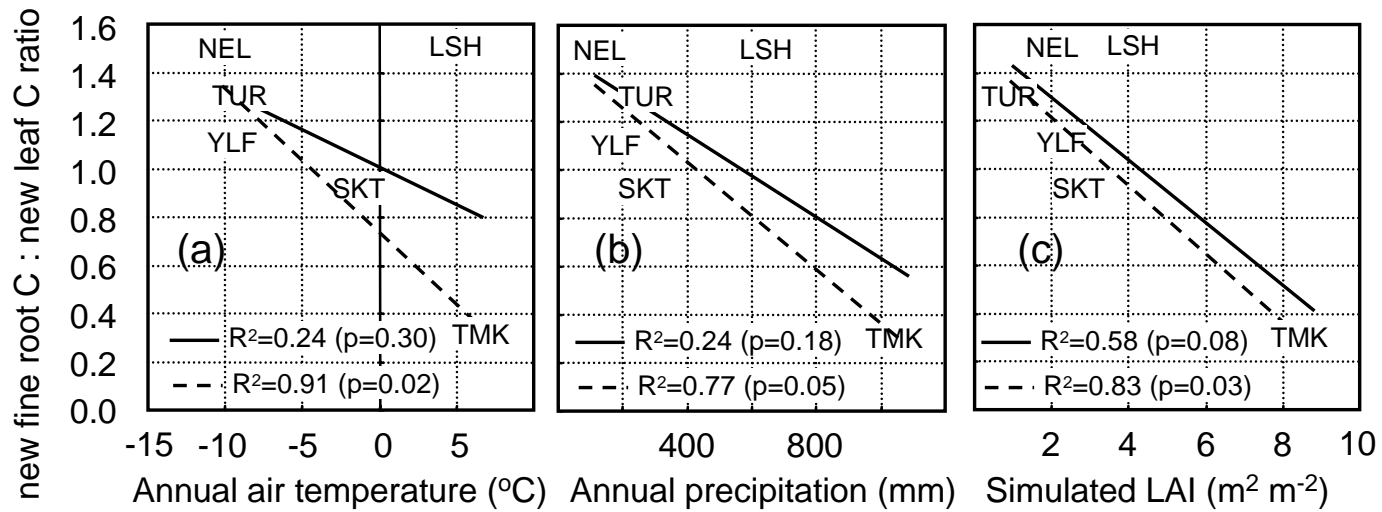

Fig. 9. Relationships between the allocation ratio of new fine root $\mathrm{C}$ to new leaf $\mathrm{C}$ and (a) mean annual air temperature, (b) total annual precipitation, and (c) LAI simulated by the improved model. Solid lines are derived from all sites, whereas dashed lines are from all sites except LSH.

The simulated NEE was weakly correlated with the annual climate (Fig. 8) in that the annual carbon sink increased with an increase of the annual mean air temperature $\left(R^{2}=0.55\right.$; $p=0.09)$, precipitation $\left(R^{2}=0.46 ; p=0.14\right)$, and radiation $\left(R^{2}=0.50 ; p=0.12\right)$. Based on the correlation coefficients between NEE and the climate variables, the annual mean air temperature was most strongly related to the spatial distribution of NEE. Although both the GPP and RE had positive correlations with the climate variables, a greater GPP induced a greater annual carbon sink, whereas a greater RE did not reduce this sink. This result suggests that the spatial distribution of NEE was generally determined by that of GPP rather than RE. Since the annual carbon budget was highly sensitive to the stand history (Fig. 7), the spatial distribution of NEE was determined by both climate variables and stand disturbance history.

In the model calibration, we adjusted the seasonality of the fluxes by changing the parameter for the allocation ratio of carbon between aboveground and belowground ( $\left.\mathrm{A}_{\text {root_leaf }}\right)$. The estimated site-specific $A_{\text {root_leaf showed a weak nega- }}$ tive correlation with the mean annual air temperature $\left(R^{2}=\right.$ $0.24 ; p=0.30)$ and total precipitation $\left(R^{2}=0.24 ; p=0.18\right)$ (Fig. 9). These trends became statistically significant $\left(R^{2}=\right.$ $0.91 ; p=0.02$ for air temperature, $R^{2}=0.77 ; p=0.05$ for total precipitation) when the relationships were estimated without LSH (dashed lines in Fig. 9), since the carbon fluxes of LSH might be affected by tree species other than larch due to the limited footprint $(\mathrm{H}$. Wang, personal communication, 2009). The negative trends indicate that the forests could allocate more carbon aboveground under warmer and wetter climate. The estimated trend of $A_{\text {root_leaf }}$ can be explained by the allocation strategy of plants that adjust resource acquisition to maximize the capture of the most limiting resource (Chapin et al., 2002); light could be the most limiting resource under a favorable climate, whereas soil water and other belowground resources might limit net primary productivity (NPP) under a cold and dry environment. A similar re- sult was reported by Vogel et al. (2008), who summarized the carbon allocation in boreal black spruce forests across North America; soil temperature was positively correlated with the aboveground NPP and negatively correlated with the belowground NPP across those sites. The higher allocation to belowground at northern sites is also consistent with the field survey of root systems at TUR. Kajimoto et al. (2003) observed the greater rooting area of the larch trees compared with the crown projected area, and concluded that the larch trees on permafrost soil competed for belowground resources rather than light. The simulated LAI was negatively correlated with the $\mathrm{A}_{\text {root_leaf }}\left(R^{2}=0.83\right)$ (Fig. 9), suggesting that $\mathrm{A}_{\text {root_leaf }}$ strongly constrained the LAI in the model simulation. The climatic condition apparently strongly controls the allocation strategy (Fig. 9a, b) and thus controls the carbon fluxes (Fig. 8) through effects of allocation on LAI (Fig. 9c). The strong correlation between $A_{\text {root_leaf }}$ and the simulated LAI indicates that the satellite-derived LAI might be useful to infer the spatial distributions of $A_{\text {root_leaf }}$ and improve the simulation of regional carbon dynamics. This allocation parameter might also be inferred from the climate data used to drive the regional simulations. Such a dynamic allocation scheme has been incorporated in some biosphere models (e.g. Friedlingstein et al. 1999; Sitch et al., 2003) and will likely improve the performance of the future projections made with the BIOME-BGC model.

\subsection{Effect of seasonal climate anomalies on the carbon cycle}

To understand the responses of carbon cycle to the weather conditions of air temperature, precipitation, VPD, and solar radiation, we examined the sensitivity of the larch forests to changes in the seasonal weather patterns (Sects. 3-4). The results of the sensitivity analysis are shown in Table 5. Spring warming enhanced the carbon sink (Table 5 case ta), but the summer and autumn warming tended to decrease the sink 
(Table 5 case tb). The spring warming enhanced GPP rather than RE except at SKT, where it resulted in the increase of the annual carbon sink (Table 5 case ta). This was because the spring warming induced the earlier onset of leaf emergence and enhanced photosynthetic activity, whereas RE was well regulated by the low soil temperature. On the other hand, summer, autumn, or winter warming decreased the annual carbon sink, except in the autumn of NEL, because the warming stimulated RE more than GPP (Table 5 case tc, te and tg). These results were consistent with the tower observations at TMK (Hirata et al., 2007), SKT (Li et al., 2005), and another Siberian site (Hollinger et al., 1998). Tree-ring data for the Siberian larch also showed that these larch trees did not benefit from mid-summer to autumn warming (Vaganov et al., 1999; Kirdyanov et al., 2003). These results suggest that the future carbon budget of larch forests depends on the changes in warming during the spring, summer, and autumn periods.

A change in precipitation substantially affected GPP and RE in SKT (Table 5 case pc and pd) in that a wetter summer enhanced both GPP and RE by mitigating the water stress to photosynthesis and decomposition. For other sites, a change in precipitation did not substantially influence GPP and RE, but it greatly influenced NEE, especially for the boreal sites of YLF, NEL, and TUR. The high sensitivity of NEE occurs because NEE is a small difference between two large fluxes. The forests of TMK and LSH did not respond strongly to the change in precipitation (Table 5 case pa-ph), a result which was consistent with the observations (Hirata et al., 2007).

The sensitivity of the annual carbon budget to the change in VPD was only obvious in the boreal summer (Table 5 case vc and vd). The higher VPD in the summer regulated GPP and thus decreased the annual sinks of the LSH, SKT, YLF, and TUR sites (Table 5 case vc). On the other hand, the lower VPD in the summer mitigated the regulation of photosynthesis at SKT, resulting in the increase of the annual sink there (Table 5 case vd). This sensitivity to VPD was consistent with the observed results for LSH (Wang et al., 2005b), SKT (Li et al., 2005), and TUR (Nakai et al., 2008) as well as a comparative study between the TMK and LSH sites (Wang et al., 2005b). The reason for the low sensitivity to VPD at the TMK site is that the summer VPD is not high enough to sufficiently reduce the stomatal conductance (Fig. 2).

The GPP in the TMK site was the most sensitive to the change in solar radiation. An increase of approximately $12 \%$ of the annual GPP resulted in an approximately $70 \%$ enhancement of the annual carbon sink, compared to the control simulation (Table 5 case sc). The decline of summer radiation greatly decreased GPP and the magnitude of negative NEE, meaning a decrease in the annual sink at the TMK site (Table 5 case sd). Among the boreal sites of LSH, SKT, YLF, NEL, and TUR, the change in the radiation did not substantially affect the GPP regardless of the season, but the annual carbon sink (negative NEE) was positively correlated with the change in summer radiation. This higher sensitivity to radiation was also reported for the observed results at TMK
(Hirata et al., 2007). Considering the sensitivity to VPD, the summer VPD could be an important factor that controls the variations of the carbon budget, but the summer radiation might become an important factor if the regulation by VPD is not strong.

The sensitivity studies identified the important weather conditions that control the annual carbon cycle in each site. In the temperate site of TMK, summer radiation was the most important control over the simulated annual carbon budget. On the other hand, summer VPD was most important in controlling the simulated annual carbon budgets of boreal sites LSH, SKT, and YLF. Air temperature was also an important controlling factor of the annual carbon budgets among all the larch forests; a warmer spring could enhance the carbon sink, but a warmer summer and autumn could decrease the sink. This temperature sensitivity was the most important controlling factor of the simulated carbon budget for the TUR and NEL sites. The sensitivity study also indicated that the small changes in GPP and RE induced large shift in the annual carbon balance, and the balance could be quite sensitive to the seasonal weather anomalies.

\subsection{Further model improvements and potential limitations}

This study, which is a first attempt to validate a terrestrial biosphere model at multiple larch forests sites in northern Eurasia to East Asia, identified several biases in the default model. Our analysis demonstrated that the calibration by the AsiaFlux observations greatly improved the BIOME-BGC model at daily, monthly, and annual time scales, and the improved model enabled us to perform more accurate sensitivity studies. However, we should note the following limitations and potential improvements.

The field-estimated GPP and RE were derived from NEE measurements during nighttime period. Nighttime fluxes by the eddy covariance technique have been recognized to contain some uncertainties (e.g., Gu et al., 2005; Papale et al., 2006). In addition to the uncertainties from nighttime measurement, it is difficult to accurately partition NEE into GPP and RE because there is no consensus on the partitioning method (Reichstein et al., 2005; Richardson and Hollinger, 2005). Although this study standardized the partitioning methodology among the sites, further studies will be required to estimate GPP and RE from field observations.

The simulated ET was still inconsistent with the observed ET at a daily time scale (Fig. 4). This disagreement was mainly caused by the intercepted evaporation term; the simulated intercepted evaporation was substantially larger during the rainy days, compared to the observed ET. Considering that the eddy covariance method could not perfectly measure ET during and just after rainfall (e.g. Kosugi et al., 2007), we could not validate the simulated intercepted evaporation. Ohta et al. (2001) reported that the intercepted evaporation was about $15 \%$ of the precipitation at the YLF site, a result 
Table 5. The sensitivity of annual GPP, RE, and NEE to changes in weather patterns of air temperature, precipitation, VPD, and solar radiation. The numbers in the table are the relative percentage as compared to the control experiment. The applied climate bias in each season was determined as 3 standard deviations of the natural variability (Table 3 ). The underscores in the table represent the values that show a high sensitivity for changing GPP and RE (more than 10\%) and NEE (more than 20\%) compared to the control experiment.

\begin{tabular}{|c|c|c|c|c|c|c|c|c|c|c|c|c|c|c|c|c|c|c|c|c|c|}
\hline & $\begin{array}{l}\text { Exami- } \\
\text { nation }\end{array}$ & & Case & $\begin{array}{r}\text { GPP } \\
\text { TMK }\end{array}$ & $\begin{array}{l}(\%) \\
\text { LSH }\end{array}$ & SKT & YLF & NEL & TUR & $\begin{array}{r}\text { RE } \\
\text { TMK }\end{array}$ & $\begin{array}{l}(\%) \\
\text { LSH }\end{array}$ & SKT & YLF & NEL & TUR & $\begin{array}{l}\text { NEE } \\
\text { TMK }\end{array}$ & $\begin{array}{r}(\%) \\
\text { LSH }\end{array}$ & SKT & YLF & NEL & TUR \\
\hline & Normal & & & 100 & 100 & 100 & 100 & 100 & 100 & 100 & 100 & 100 & 100 & 100 & 100 & 100 & 100 & 100 & 100 & 100 & 100 \\
\hline \multirow{8}{*}{$\begin{array}{l}\text { Air } \\
\text { temperature }\end{array}$} & spring & + & $\mathrm{ta}$ & 113 & 109 & $\underline{110}$ & 106 & 109 & 119 & 109 & 108 & 112 & 105 & 102 & 115 & 142 & 136 & 99 & 111 & 224 & 158 \\
\hline & spring & - & $\mathrm{tb}$ & $\underline{87}$ & 91 & $\frac{99}{99}$ & 96 & 95 & 92 & 91 & 93 & 98 & 97 & 112 & 91 & 53 & $\underline{59}$ & 105 & 89 & -179 & 100 \\
\hline & summer & + & tc & $\frac{98}{98}$ & 102 & 110 & 107 & 111 & 115 & 104 & 106 & 123 & 117 & 112 & 121 & 42 & 45 & 46 & 44 & 90 & 67 \\
\hline & summer & - & $\mathrm{td}$ & 100 & 98 & $\underline{80}$ & 87 & $\underline{87}$ & $\underline{82}$ & 95 & 94 & $\underline{80}$ & $\underline{84}$ & 90 & $\underline{81}$ & 144 & $\underline{146}$ & 77 & $\overline{105}$ & 37 & 91 \\
\hline & autumn & + & te & 100 & 101 & 107 & 103 & 109 & 110 & 103 & 105 & 110 & 110 & 108 & 119 & $\underline{73}$ & $\underline{56}$ & 91 & 59 & 128 & -22 \\
\hline & autumn & - & $\mathrm{tf}$ & 99 & 98 & 95 & 95 & 93 & 91 & 97 & 96 & 96 & 93 & 97 & 88 & 123 & 126 & 90 & 104 & 35 & 119 \\
\hline & winter & + & $\operatorname{tg}$ & 98 & 100 & 100 & 99 & 102 & 101 & 100 & 102 & 105 & 104 & 104 & $\overline{106}$ & $\overline{81}$ & $\underline{62}$ & 75 & 63 & $\overline{73}$ & 61 \\
\hline & winter & - & th & 102 & 100 & 100 & 101 & 98 & 100 & 100 & 98 & 97 & 96 & 96 & 96 & $\underline{125}$ & $\underline{135}$ & 114 & 128 & $\underline{123}$ & 140 \\
\hline \multirow[t]{8}{*}{ Precipitation } & spring & + & pa & 100 & 100 & 107 & 103 & 108 & 100 & 100 & 100 & 104 & 107 & 104 & 100 & 99 & 99 & 121 & 72 & 24 & 100 \\
\hline & spring & - & $\mathrm{pb}$ & 100 & 99 & 89 & 96 & 94 & 100 & 100 & 99 & 96 & 94 & 91 & 100 & 99 & 105 & $\frac{121}{58}$ & $\frac{f 2}{111}$ & 134 & 100 \\
\hline & summer & + & $\mathrm{pc}$ & 100 & 100 & $\underline{122}$ & 104 & $\underline{115}$ & 100 & 100 & 101 & 126 & 108 & $\underline{132}$ & 101 & 97 & 95 & 101 & 80 & $-\overline{136}$ & 97 \\
\hline & summer & - & pd & 100 & 99 & $\underline{67}$ & 90 & 89 & 99 & 100 & 98 & 82 & 94 & $\underline{85}$ & 97 & 97 & 117 & -9 & $\underline{63}$ & 140 & 126 \\
\hline & autumn & + & pe & 100 & 100 & $\frac{103}{103}$ & 100 & 107 & 100 & 100 & 101 & $\frac{1}{103}$ & 100 & 115 & 100 & 98 & 86 & $\overline{102}$ & $\frac{0}{100}$ & -5 & 100 \\
\hline & autumn & - & $\mathrm{pf}$ & 100 & 100 & 97 & 100 & 92 & 100 & 99 & 99 & 97 & 100 & $\underline{89}$ & 100 & 109 & 118 & 95 & 100 & $\frac{5}{140}$ & 101 \\
\hline & winter & + & pg & 100 & 100 & 100 & 101 & 104 & 100 & 100 & 100 & 100 & 102 & 107 & 100 & 101 & 100 & 101 & 94 & 63 & 100 \\
\hline & winter & - & ph & 100 & 100 & 100 & 99 & 96 & 100 & 100 & 100 & 100 & 98 & 94 & 100 & 100 & 100 & 99 & 105 & 122 & 100 \\
\hline \multirow[t]{8}{*}{ VPD } & spring & + & va & 100 & 99 & 98 & 100 & 98 & 100 & 100 & 100 & 99 & 100 & 98 & 100 & 100 & 92 & 93 & 101 & 109 & 100 \\
\hline & spring & - & $\mathrm{vb}$ & 100 & 100 & 102 & 100 & 102 & 100 & 100 & 100 & 101 & 100 & 103 & 100 & 99 & 102 & 109 & 99 & 83 & 100 \\
\hline & summer & + & $\mathrm{vc}$ & 99 & 92 & 83 & 88 & 92 & 98 & 99 & 98 & 93 & 97 & 101 & 99 & 104 & -1 & 38 & 28 & -30 & 90 \\
\hline & summer & - & $\mathrm{vd}$ & 100 & 102 & $\underline{122}$ & $\underline{110}$ & $\underline{112}$ & 101 & 100 & 101 & 118 & 111 & 120 & 101 & 97 & $\overline{114}$ & 145 & 105 & $\underline{3}$ & 101 \\
\hline & autumn & + & ve & 100 & 100 & 98 & 99 & 99 & 100 & 100 & 99 & 98 & $\overline{100}$ & 98 & 100 & 100 & 104 & 96 & 97 & 108 & 100 \\
\hline & autumn & - & vf & 100 & 100 & 103 & 101 & 102 & 100 & 100 & 101 & 104 & 100 & 103 & 100 & 99 & 87 & 101 & 102 & 81 & 100 \\
\hline & winter & + & $\mathrm{vg}$ & 100 & 100 & 100 & 100 & 100 & 100 & 100 & 100 & 100 & 100 & 100 & 100 & 100 & 100 & 100 & 100 & 100 & 100 \\
\hline & winter & - & vh & 100 & 100 & 100 & 100 & 100 & 100 & 100 & 100 & 100 & 100 & 100 & 100 & 100 & 100 & 100 & 100 & 100 & 100 \\
\hline \multirow{8}{*}{$\begin{array}{l}\text { Solar } \\
\text { Radiation }\end{array}$} & spring & + & $\mathrm{sa}$ & 101 & 100 & 100 & 100 & 100 & 100 & 100 & 100 & 100 & 100 & 100 & 100 & 104 & 103 & 99 & 100 & 102 & 100 \\
\hline & spring & - & $\mathrm{sb}$ & 99 & 100 & 100 & 100 & 100 & 100 & 99 & 100 & 100 & 100 & 100 & 100 & 93 & 97 & 101 & 100 & 98 & 100 \\
\hline & summer & + & $\mathrm{sc}$ & 112 & 102 & 100 & 102 & 100 & 102 & 106 & 100 & 99 & 99 & 97 & 100 & 170 & 124 & 100 & 118 & 136 & 118 \\
\hline & summer & - & sd & $\underline{86}$ & 98 & 101 & 97 & 100 & 98 & 93 & 100 & 101 & 101 & 103 & 100 & 22 & 70 & 100 & 76 & $\underline{50}$ & 79 \\
\hline & autumn & + & $\mathrm{se}$ & 103 & 101 & 100 & 100 & 100 & 100 & 101 & 100 & 100 & 100 & 100 & 100 & 117 & 111 & 101 & $\overline{102}$ & 108 & 103 \\
\hline & autumn & - & $\mathrm{sf}$ & 97 & 99 & 100 & 100 & 100 & 99 & 99 & 100 & 100 & 100 & 101 & 100 & 83 & 88 & 99 & 98 & 89 & 95 \\
\hline & winter & + & $\mathrm{sg}$ & 100 & 100 & 100 & 100 & 100 & 100 & 100 & 100 & 100 & 100 & 100 & 100 & 100 & 100 & 100 & 100 & 100 & 100 \\
\hline & winter & - & $\mathrm{sh}$ & 100 & 100 & 100 & 100 & 100 & 100 & 100 & 100 & 100 & 100 & 100 & 100 & 100 & 100 & 100 & 100 & 100 & 100 \\
\hline
\end{tabular}

which is consistent with the simulated intercepted evaporation value of about $18 \%$ of the precipitation. The parameter for the canopy interception was needed to be site specific for the LSH site, which was probably caused by the limited footprint in this site (H. Wang, personal communication, 2009). Observed ET by the eddy covariance measurements also has uncertainties due to the energy imbalance problem (Wilson et al., 2002). The energy balance ratio at our study sites ranged from $66 \%$ to $100 \%$ (Hirata et al., 2005; Liu et al., 2005; Wang et al., 2005; Nakai et al., 2008; Ohta et al., 2008), suggesting significant uncertainties in observed ET and potentially in the field-estimated carbon fluxes. Consequently, further investigation for both observation and modeling might be required to reveal the cause of the inconsistency.

Although the simulated sensitivities to air temperature, VPD and radiation were consistent with the observed studies, the simulated response to precipitation still had large uncertainties. At the sites of TMK and LSH, the amount of precipitation did not substantially affect the modeled carbon budget; which was consistent with observations. On the other hand, precipitation substantially affected the carbon budgets in the northern sites of SKT, YLF, NEL, and TUR. Although the discrepancy in NEE might be exaggerated by small errors of the two large terms, the errors were partly caused by a lack of important processes in the model, such as the water supply from the deeper layer that the larch trees use when the water supply in the upper soil layer is limited ( $\mathrm{Li}$ et al., 2006). Studies at YLF (Ohta et al., 2008) and NEL (Machimura et al., 2007) showed a 1-year lag of the carbon and water fluxes to precipitation probably due to the availability of water stored in the permafrost. Consequently, further improvements of the model may be required to properly represent the response to water availability. Other factors that might contribute to the discrepancy may be understory vegetation and/or permafrost dynamics (Ueyama et al., 2009).

The BIOME-BGC model considers only tree species in ecosystem, but larch stands generally consist of sparse canopy, coexisting with other species. Our study sites also contain understory vegetation other than larch (shown in Sect. 2.1), which may influence carbon dynamics.

Our simulation showed that the stand history was the most important factor for predicting the carbon budget (Fig. 7). 
Although the spatial distribution of NEE was also highly sensitive to the climate variables (Fig. 8), the observed large carbon sink of TMK and SKT could not be reproduced without the stand history. These results suggest that the availability of information on stand history could improve the carbon budget simulation both at stand (the YLF, NEL, and TUR sites, where stand history was not available) and regional scales.

Several model assimilation studies point out the problem of model equifinality in that many different model parameterizations are able to reproduce the observed data (e.g. Franks et al., 1997; Schulz et al., 2001). To minimize the problem of the model equifinality, we (1) modified the submodels by carefully checking the default model output with field observations other than the carbon and water fluxes, (2) examined the high sensitive parameters across the multiple sites through the sensitivity analysis, and (3) updated the parameters mainly from the values available in the literature. In addition to validation of the current status of the fluxes, we also validated the ecosystem sensitivity to the seasonal weather anomalies, and obtained a reasonable sensitivity compared with the observed studies in each site. Consequently, the parameters are applicable to simulate the current status of larch forests of the multiple sites. While the model is well validated in this study, further data acquisition will improve the model parameterizations.

In this study, we initialized the model with the short-term meteorology at the tower sites rather than the long-term meteorological records from the weather stations near the sites, in order to avoid biases due to data discontinuities. Although the meteorological years used in this study did not substantially deviate from the long-term average (Nakai et al., 2008; Ohta et al., 2008; Hirata et al., 2007), this initialization might lead to some biases in the simulation. Since the historical changes in the climate affect the carbon and water cycles through various indirect feedbacks, such as changes in the pool size (Keyser et al., 2000; Ueyama et al., 2009), the use of short-term meteorology might ignore these effects and lead to simulations that were more indicative of the steady state condition compared with the actual carbon and water cycles. The underestimation of the annual carbon sink by the model simulation (Fig. 6) might also be caused by this initialization process. Since the simulation of sensitivity to the seasonal weather conditions (Table 5) has been conducted for a short-term change (interannual time scale), the response of the carbon and water cycles to the long-term climate anomalies (e.g. decadal or longer time scales) should be examined in future studies.

\section{Conclusions}

The regional network of tower flux measurements, AsiaFlux, helped improve the model performance of the BIOME-BGC for larch forests in East Asia. Using the flux data at six sites from Siberian subarctic to cool temperate regions, we deter- mined new general parameters for larch forests. The use of these validated parameters will allow us to conduct regionalscale simulations. The site-specific parameter of the allocation ratio of new fine root $\mathrm{C}$ to new leaf $\mathrm{C}$ was negatively correlated with the annual climatology of air temperature and precipitation; this strongly constrained the simulated LAI. In the regional scale simulation, the allocation parameter will be estimated from climate data or satellite derived LAI.

The model simulations showed that the spatial variations of GPP and RE were correlated with the variations in the annual climatology of air temperature and/or precipitation. In addition to the climatic conditions, the stand history was another important factor for explaining the spatial variations of NEE. These simulation results suggest that the spatial map of the disturbance history, such as plantation areas and fire, will be important for the projection of the regional scale carbon budget. For the future projections of the carbon cycle, the BIOME-BGC model will necessarily be coupled with a sophisticated disturbance algorithm at regional and continental scales.

The sensitivity analysis showed that spring warming could enhance the carbon sink, but summer and autumn warming could decrease the carbon sink; this is consistent with the observed results. In one temperate site, where water conditions did not regulate the carbon cycle, summer radiation was the most important factor that controlled the annual carbon budget. On the other hand, summer VPD strongly regulated the annual carbon sink in the boreal sites. Our analysis has allowed us to understand sensitivity at seasonal to interannual time scales, but it is not clear how long-term changes in climate affect the carbon and water cycles through various feedback processes. These projections should be examined in ongoing and long-term observations.

Through comparison to observations, the model uncertainties have been addressed in this study, especially for boreal regions. It is possible that the modeled response to the water conditions is inaccurate. In some boreal sites, the regulation of stomatal conductance and heterotrophic respiration by the water deficit might be overestimated. These discrepancies could be due to various causes, such as water storage in deeper soil layers, the effects of understory vegetation, and permafrost dynamics. Additional validation with available chamber and biometric measurements will help reduce the model uncertainties.

Acknowledgements. This work was supported by JSPS A3 Foresight Program (CarboEastAsia). We are grateful to Dr. Akihiko Ito of the National Institute for Environmental Studies and two anonymous reviewers for making constructive comments. We thank all the people who contributed to the field observations, data analysis, and synthesis. BIOME-BGC was provided by the Numerical Terradynamic Simulation Group (NTSG) at the University of Montana.

Edited by: J. Kim 


\section{References}

Amthor, J. S., Chen, J. M., Clein, J. S., Frolking, S. E., Goulden, M. L. Grant, R. F., Kimball, J. S., King, J. S., McGuire, A. D., Nikolov, N. T., Potter, C. S., Wang, S., and Wofsy, S. C.: Boreal forest $\mathrm{CO}_{2}$ exchange and evapotranspiration predicted by nine ecosystem process models: Intermodel comparisons and relationships to field measurements, J. Geophys. Res., 106, 33623 33648, 2001.

Baldocchi, D. D., Falge, E., Gu, L., Olson, R., Hollinger, D., Running, S., Anthoni, P., Nernhofer, C., Davis, K., Evans, R., Fuentes, J., Goldstein, A., Katul, G., Law, B., Lee, X., Malhi, Y., Meyers, T., Munger, W., Oechel, W., Paw, U, K. T., Pilegaard, K., Schmid, H. P., Valentini, R., Verma, S., Vesala, T., Wilson, K., and Wofsy, S.: FLUXNET: A new tool to study the temporal and spatial variability of ecosystem-scale carbon dioxide, water vapor, and energy flux densities, B. Am. Meteorol. Soc., 82, 2415-2434, 2001.

Chapin III, F. S., Matson, P. A., and Mooney, H. A.: Principles of terrestrial ecosystem ecology, Springer-Verlag Press, New York, 436 pp., 2002.

Chapin III, F. S., Sturm, M., Serreze, M. C., McFadden, J. P., Key, J. R. Lloyd, A. H. McGuire, A. D., Rupp, T. S., Lynch, A. H., Schimel, J. P., Beringer, W. L. Chapman, W. L., Epstein, H. E., Euskirchen, E. S., Hinzman, L. D., Jia, G., Ping, C. L., Tape, K. D., Thompson, C. D. C., Walker, D. A., and Welker, J. M.: Role of land-surface changes in arctic summer warming, Science, 310 , 657-660, 2005.

Cienciala, E., Running, S. W., Lindroth, A., Grelle, A., and Ryan, M. G.; Analysis of carbon and water fluxes from the NOPEX boreal forest: comparison of measurements with FOREST-BGC simulations, J. Hydrol., 212-213, 62-78, 1998.

Clein, J. S., McGuire, A. D., Zhang, X., Kicklighter, D. W., Melillo, J. M., Wofsy, S. C., Jarvis, P. G., and Massheder, J. M.: Historical and projected carbon balance of mature black spruce ecosystems across north America: the role of carbon-nitrogen interaction, Plant Soil, 242, 15-32, 2002.

Dolman, A. J., Maximov, T. C., and Ohta, T.: Water and energy exchange in East Siberian forest: an introduction, Agr. Forest Meteorol., 148, 1913-1915, 2008.

Dolman, A. J., Maximov, T. C., Moors, E. J., Maximov, A. P., Elbers, J. A., Kononov, A. V., Waterloo, M. J., and van der Molen, M. K.: Net ecosystem exchange of carbon dioxide and water of far eastern Siberian Larch (Larix cajanderii) on permafrost, Biogeosciences, 1, 133-146, 2004,

http://www.biogeosciences.net/1/133/2004/.

Engstrom, R., Hope, A., Kwon, H., Harazono, Y., Mano, M., and Oechel, W.. Modeling evapotranspiration in Arctic coastal plain ecosystems using a modified BIOME-BGC model, J. Geophys. Res., 111, G02021, doi:10.1029/2005JG000102, 2006.

Enting, I., Wigley, T., and Heimann M.: Future emissions and concentrations of carbon dioxide: key ocean/atmosphere/land analyses, CSIRO Division of Atmospheric Research Technical Paper 31, 120 pp., 1994.

Euskirchen, E. S., McGuire, A. D., Kicklighter, D. W., Zhuang, Q., Clein, J. S., Dargaville, R. J., Dye, D. G., Kimball, J. S., McDonald, K. C., Melillo, J. M., Romanovsky, V. E., and Smith, N. V.: Importance of recent shifts in soil thermal dynamics on growing season length, productivity, and carbon sequestration in terrestrial high-latitude ecosystems, Glob. Change Biol., 12, 731-750,
2006.

Farquhar, G. D., Von Caemmerer, S., and Berry, J. A.: A biochemical model of photosynthetic $\mathrm{CO}_{2}$ assimilation in leaves of $\mathrm{C}_{3}$ species, Planta 149, 79-90, 1980.

Franks, S. W., Beven, K. J., Quinn, P. F., and Wright, I. R.: On the sensitivity of soil-vegetation-atmosphere transfer (SVAT) schemes: equifinality and the problem of robust calibration, Agr. Forest Meteorol., 86, 63-75, 1997.

Friedlingstein, P., Joel, G., Field, C. B., and fung, I. Y.: Towerd an allocation scheme for global terrestrial carbon models, Glob. Change Biol., 5, 755-770, 1999.

Gower, S. T. and Richards, J. H.: Larches: Deciduous conifers in an evergreen world, Bioscinece, 40, 818-826, 1990.

Grant, R. F., Arain, A., Arora, V., Barr, A., Black, T. A., Chen, J., Wang, S., Yuan, F., and Zhang, Y.: Intercomparison of techniques to model high temperature effects on $\mathrm{CO}_{2}$ and energy exchange in temperate and boreal coniferous forests, Ecol. Model., 188, 217-252, 2005.

Gu, L., Falge, E., Boden, T., Baldocchi, D. D., Black, T. A., Saleska, S. R., Suni, T, Verma, S. B., Vesala, T., Wofsy, S. C., and Xu, L.: Objective threshold determination for nighttime eddy flux filtering, Agr. Forest Meteorol., 128, 179-197, 2005.

Hinzman, L. D., Bettez, N. D., Bolton, W. R., Chapin, F. S., Dyurgerov, M. Fastie, C. L., Griffith, B., Hollister, R. D., Hope, A., Huntington, H. P., Jensen, A. M., Jia, G. J., Jorgenson, T., Kane, D. L., Klein, D. R., Kofinas, G., Lynch, A. H., Lloyd, A. H., McGuire, A. D., Nelson, F. E., Oechel, W. C., Osterkamp, T. E., Racine, C. H., Romanovsky, V. E., Stone, R. S., Stow, D. A., Sturm, M., Tweedie, C. E., Vourlitis, G. L., Walker, M. D., Waker, D. A., Webber, P. J., Welker, J. M., Winker, K. S., and Yoshikawa, K.: Evidence and implications of recent climate change in northern Alaska and other arctic regions, Climatic Change, 72, 251-298, 2005.

Hirano, T., Hirata, R., Fujinuma, Y., Saigusa, N., Yamamoto, S., Harazono, Y., Takeda, M., Inukai, K., and Inoue, G.: $\mathrm{CO}_{2}$ and water vapor exchange of a larch forest in northern Japan, Tellus B, 55, 244-257, 2003.

Hirata, R., Hirano, T., Okada, K., Fujinuma, Y., Inukai, K., Saigusa, N., and Yamamoto, S.: Effect of wind speed and direction on eddy fluxes over a larch plantation, J. Agr. Meteorol., 60, 741$744,2005$.

Hirata, R., Hirano, T., Saigusa, N., Fujinuma, Y., Inukai, K., Kitamori, Y., Takahashi, Y., and Yamamoto, S.: Seasonal and interannual variations in carbon dioxide exchange of a temperate larch forest, Agr. Forest Meteorol., 147, 110-124, 2007.

Hirata, R., Saigusa, N., Yamamoto, S., Ohtani, Y., Ide, R., Asanuma, J., Gamo, M., Hirano, T., Kondo, H., Kosugi, Y., Li, S.-G., Nakai, Y., Takagi, K., Tani, M., and Wang, H.: Spatial distribution of carbon balance in forest ecosystems across East Asia, Agr. Forest Meteorol., 148, 761-775, 2008.

Hollinger, D. Y., Kelliher, F. M., Schulze, E.-D., Bauer, G., Arneth, A., Byers, J. N., Hunt, J. E., McSeveny, T. M., Kobak, K. I., Milukova, I., Sogatchev, A., Tatarinov, F., Varlargin, A., Ziegler, W., and Vygodskaya, N. N.: Forest-atmosphere carbon dioxide exchange in eastern Siberia. Agr. Forest Meteorol., 90, 291-306, 1998.

IPCC: IPCC (Intergovernmental Panel on Climate Change), Climate Change 2007: Synthesis report Contribution of Working Groups I, II, and III to the Fourth Assessment Report of the In- 
tergovernmental Panel on Climate Change, Cambridge University Press, Cambridge, UK, 104 pp, 2007.

Jarvis, P. G.: The interpretation of the variations in leaf water potential and stomatal conductance found in canopies in the field, Phill. Trans. R. Soc. Lond. B, 273, 593-610, 1976.

Keyser, A. R., Kimball, J. S., Nemani, R. R., and Running, S. W.: Simulating the effects of climate change on the carbon balance of north American high-latitude forests, Glob. Change Biol., 6, $185-195,2000$

Kajimoto, T., Matsuura, Y., Osawa, A., Prokushkin, A. S., Sofronov, M. A., and Abaimov, A. P.: Root system development of Larix gmelinii trees affected by micro-scale conditions of permafrost soils in central Siberia, Plant Soil, 255, 281-292, 2003.

Kajimoto, T., Matsuura, Y., Sofronov, M. A., Volokitina, A. V., Mori, S., Osawa, A., and Abaimov, A. P.: Above- and belowground biomass and net primary productivity of a Larix gmelinii stand near Tura, central Siberia, Tree Physiol., 19, 815-822, 1999.

Kim, H., Hirano, T., and Urano, S.: Seasonal variation in $\mathrm{CO}_{2}$ production of leaf litter from different deciduous forest at the early decomposition stage, J. Agr. Meteorol., 61, 95-104, 2005.

Kimball, J. S., McDonald, K. C., Running, S. W., and Frolking, S. E.: Satellite radar remote sensing of seasonal growing seasons for boreal and subapline evergreen forests, Remote Sens. Environ., 90, 243-258, 2004.

Kimball, J. S., Thornton, P. E., White, M. A., and Running, S. W.: Simulating forest productivity and surface-atmosphere carbon exchange in the BOREAS study region, Tree Physiol., 17, 589-599, 1997a.

Kimball, J. S., White, M. A., and Running, S. W.: BIOME-BGC simulations of stand hydrologic processes for BOREAS, J. Geophys. Res., 102, 29043-29051, 1997b.

Kimball, J. S., Zhao, M., McGuire, A. D., Heinsch, F. A., Clein, J., Calef, M., Jolly, W. M., Kang, S., Euskirchen, S. E., McDonald, K. C., and Running, S. W.: Recent climate-driven increases in vegetation productivity for the western arctic: evidence of an acceleration of the northern terrestrial carbon cycle, Earth Interactions, 11, 1-30, 2007.

Kirdyanov, A., Houghes, M., Vaganov, E., Schweingruber, F., and Silkin, P.: The importance of early summer temperature and data of snow melt for tree growth in the Siberian Subarctic, Trees, 17, 61-69, 2003.

Kosugi, Y., Takanashi, S., Tanaka, H., Ohkubo, S., Tani, M., Yano, M., and Katayama, T.: Evapotranspiration over a Japanese cypress forest. I. Eddy covariance fluxes and surface conductance characteristics for 3 years, J. Hydrol., 337, 269-283, 2007.

Li, S.-G., Asanuma, J., Kotani, A., Eugster, W., Davaa, G., Oyunbaatar, D., and Sugita, M.: Year-round measurements of net ecosystem $\mathrm{CO}_{2}$ flux over a montane larch forest in Mongolia, J. Geophys. Res., 110, D0930, doi:10.1029/2004JD005453, 2005.

Li, S.-G., Tsujimura, M., Sugimoto, A., Davaa, G., Oyunbaatar, D., and Sugita, M.: Temporal variation of ${ }^{13} \delta \mathrm{C}$ of larch leaves from a montane boreal forest in Mongolia, Trees, 21, 479-490, 2007.

Li, S.-G., Tsujimura, M., Sugimoto, A., Sasaki, L., Yamanaka, T., Davaa, G., Oyunbaatar, D., and Sugita, M.: Seasonal variation in oxygen isotope composition of waters for a montane larch forest in Mongolia, Trees, 20, 122-130, 2006.

Machimura, T., Iwahana, G., Lopez, L., Kobayashi, Y., Okabe, T., Yamada, Y., Hirano, T., Fukuda, M., and Fedorov, A. N.: Gross primary productivity, ecosystem respiration and net ecosystem exchange observed at a few intact and disturbed forests near Yakutsk, Eastern Siberia, Proceedings of International Workshop on: Tropical rain forest and boreal forest disturbance and their affects on global warming, 1-7, 2007.

Machimura, T., Kobayashi, Y., Iwahana, G., Hirano, T., Lopez, L., Fukuda, M. and Fedorov, A., N.: Change of carbon dioxide budget during three years after deforestation in eastern Siberian larch forest, J. Agr. Meteorol., 60, 653-656, 2005.

Manabe, S., Spelman, M. J., and Stouffer, R. J.: Transient responses of a coupled ocean-atmosphere model to gradual changes of atmospheric $\mathrm{CO}_{2}$. part II: seasonal response, J. Climate, 5, 105126, 1992.

Matyssek, R. and Schulze, E.-D.: Heterosis in hybrid larch (Larix deciduas $\mathrm{x}$ leptolepis), Trees, 225-231, 1987.

Mizoguchi, Y., Miyata, A., Ohtani, Y., Hirata, R., and Yuta, S.: A review of tower observation sites in Asia, J. For. Res-Jpn., 14, $1-9,2009$.

Myneni, R. B., Dong, J., Tucker, C. J., Kaufmann, R. K., Kauppi, P. E., Kauppi, P. E., Liski, J., Zhou, L., Alexeyev, V., and Hughes, M. K.: A large carbon sink in the woody biomass of northern forests, P. Natl. Acad. Sci. USA, 98, 14784-14789, 2001.

Nakai, Y., Matsuura, Y., Kajimoto, T., Abaimov, A. P., Yamamoto, S., and Zyryanova, O. A.: Eddy covariance $\mathrm{CO}_{2}$ flux above a Gmelin larch forest on continuous permafrost in central Siberia during a growing season, Theor. Appl. Climatol., 93, 133-147, 2008.

Ohta, T., Hiyama, T., Tanaka, H., Kuwada, T., Maximov, T. C., Ohata, T., and Fukushima, Y.: Seasonal variation in the energy and water exchanges above and below a larch forest in eastern Siberia, Hydrol. Process, 15, 1459-1476, 2001.

Ohta, T., Maximov, T. C., Dolman, A. J., Nakai, T., van der Molen, M. K., Kononov, A. V., Maximov, A. P., Hiyama, T., Iijima, Y., Moors, E. J., Tanaka, H., Toba, T., and Yabuki, H.: Interannual variation of water balance and summer evapotranspiration in an eastern Siberian larch forest over a 7-year period (1998-2006), Agr. Forest Meteorol., 148, 1941-1953, 2008.

Papale, D., Reichstein, M., Aubinet, M., Canfora, E., Bernhofer, C., Kutsch, W., Longdoz, B., Rambal, S., Valentini, R., Vesala, T. and Yakir, D.: Towards a standardized processing of Net Ecosystem Exchange measured with eddy covariance technique: algorithms and uncertainty estimation, Biogeosciences, 3, 571-583, 2006, http://www.biogeosciences.net/3/571/2006/.

Piao, S., Ciais, P., Friedlingstein, P., Peylin, P., Reichstein, M., Luyssaert, S., Margolis, H., Fang, J., Barr, A., Chen, A., Grelle, A., Hollinger, D. Y., Laurila, T., Lindroth, A., Richardson, A. D., and Vesala, T.: Net carbon dioxide losses of northern ecosystems in response to autumn warming, Nature, 451, 49-53, 2007.

Pietsch, S. A., Hasenauer, H., and Thornton, P. E.,: BGC-model parameters for tree species growing in central European forests, Forest Ecol. Manag., 211, 264-295, 2005.

Reichstein, M., Falge, E., Baldocchi, D., Papale, D., Aubinet, M., Berbigier, P., Bernhofer, C., Buchmann, N., Gilmanov, T., Granier, A., Grünwald, T., Havrânkovâ, K., Ilvesniemi, H., Janous, D., Knohl, A., Laurila, T., Lohila, A., Loustau, D., Matteucci, G., Meyers, T., Miglietta, F., Ourcival, J. -M., Pumpanen, J., Rambal, S., Rotenberg, E., Sanz, M., Tenhunen, J., Seufert, G., Vaccari, F., Vesala, T., Yakir, D., and Valentini, R.: On 
the separation of net ecosystem exchange into assimilation and ecosystem respiration: review and improved algorithm, Glob. Change Biol., 11, 1-16, 2005.

Richardson, A. D. and Hollinger, D. Y.: Statistical modeling of ecosystem respiration using eddy covariance data: maximum likelihood parameter estimation, and Monte Carlo simulation of model and parameter uncertainty, applied to three simple models, Agr. Forest Meteorol., 131, 191-208, 2005.

Running, S. W. and Coughlan, J. C.: A general model of forest ecosystem processes for regional applications I. Hydrologic balance, canopy gas exchange and primary production processes, Ecol. Model., 42, 125-154, 1988.

Saigusa, N., Yamamoto, S., Hirata, R., Ohtani, Y., Ide, R., Asanuma, J., Gamo, M., Hirano, T., Kondo, H., Kosugi, Y., Li, S.-G., Nakai, Y., Takagi, K., Tani, M., and Wang, H.: Temporal and spatial variations in the seasonal patterns of $\mathrm{CO}_{2}$ flux in boreal, temperate, and tropical forests in East Asia, Agr. Forest Meteorol., 148, 700-713, 2008.

Schulz, K., Jarvis, A., and Beven, K.: The predictive uncertainty of land surface fluxes in response to increasing ambient carbon dioxide, J. Climate, 14, 2551-2562, 2001.

Schulze, E.-D., Lloyd, J., Kelliher, F. M., Wirth, C., Rebmann, C., Luhker, B., Mund, M., Knohl, A., Milyukova, I. M., Schulze, W., Ziegler, W., Varlagin, A. $\beta$., Sogachev, A. F., Valentini, R., Dore, S., Grigoriev, S., Kolle, O., Panfyorov, M. I., Tchebakova, N., and Vygodskaya, N. N.: Productivity of forests in the Eurosiberian boreal region and their potential to act as a carbon sink a synthesis, Glob. Change Biol., 5, 703-722, 1999.

Sitch, S., Smith, B., Prentice, I. C., Arneth, A., Bondeau, A., Cramer, W., Kaplan, J. O., Levis, S., Lucht, W., Sykes, M. T., Thonicke, K., and Venevsky, S.: Evaluation of ecosystem dynamics, plant geography and terrestrial carbon cycleing in the LPJ dynamic global vegetation model, Glob. Change Biol., 9, 161-185, 2003.

Tans, P. P. and Conway, T. J.: Monthly atmospheric $\mathrm{CO}_{2}$ mixing ratios from the NOAA CMDL carbon cycle cooperative global air sampling network, 1968-2002, In Trends: A compendium of data on global change. carbon dioxide information analysis center, Oak Ridge National Laboratory, U.S. Department of Energy, Oak Ridge, Tenn., U.S.A, 2005.

Turner, D. P., Ritts, W. D., Cohen, W. B., Gower, S. T., Zhao, M., Running, S. W., Wofsy, S. C., Urbanski, S., Dunn, A. L., and Munger, J. W.: Scaling gross primary production (GPP) over boreal and deciduous forest landscapes in support of MODIS GPP product validation, Remote Sens. Environ., 88, 256-270, 2003.

Thornton, P. E., Law, B. E., Gholz, H. L., Clark, K. L., Falge, E., Ellsworth, D. S., Goldstein, A. H., Monson, R. K., Hollinger, D., Falk, M., Chen, J., and Sparks, J. P.: Modeling and measuring the effects of disturbance history and climate on carbon and water budgets in evergreen needle forests, Agr. Forest Meteorol., 113, $185-222,2002$.

Ueyama, M., Harazono, Y., Kim, Y., and Tanaka, N.: Response of the carbon cycle in sub-arctic black spruce forests to climate change; reduction of a carbon sink related to the sensitivity of heterotrophic respiration, Agr. Forest Meteorol., 149, 582-602, 2009.

Vaganov, E. A., Hughes, M. K., Kirdyanov, A. V., Schweingruber, F. H., and Silkin, P. P.: Influence of snowfall and melt timing on tree growth in subarctic Eurasia, Nature, 400, 149-151, 1999.
Valentini, R., Matteucci, G., Dolman, A. J., Schulze, E. -D., Rebmann, C., Moors, E. J., Granier, A., Gross, P., Jensen, N. O., Pilegaard, K., Lindroth, A., Grelle, A., Bernhofer, C., Grûnwald, T., Aubinet, M., Ceulemans, R., Kowalski, A.S., Vesala, T., Rannik, U., Berbigier, P., Loustau, D., Guðmundsson, J., Thorgeirsson, H., Lbrom,A. Morgenstern, K., Clement, R., Moncrieff, J., Montagnani, L., Minerbi, S., and Jarvis, P. G.: Respiration as the main determinant of carbon balance in European forests, Nature, 404, 861-865, 2000.

Vogel, J., Bond-Lamberty, B. P., Schuur, E. A. G., Gower, S., Mack, M. C., O'Connell, K. B. O., Valentine, D. W., and Ruess, R. W.: Carbon allocation in boreal black spruce forests across regions varying in soil temperature and precipitation, Glob. Change Biol., 14, 1503-1516, 2008.

Vygodskaya, N. N., Milyukova, I., Varlagin, A., Tatarinov, F., Sogachev, A., Kobak, K. I., Desyatkin, R., Bauer, G., Hollinger, D. Y., Kelliher, F. M., and Schulze, E.-D.: Leaf conductance and $\mathrm{CO}_{2}$ assimilation of Larix gmelinii growing in an eastern Siberian boreal forest, Tree Physiol., 17, 607-615, 1997.

Wang, H. Zu, Y., Saigusa, N., Yamamoto, S., Kondo, H., Yang, F., and Wang, W.: $\mathrm{CO}_{2}$, water vapor and energy fluxes in a larch forest in northeast China, J. Agr. Meteorol., 60, 549-552, 2005 a.

Wang, H., Saigusa, N., Zu, Y., Yamamoto, S., Kondo, H., Yang, F., Wang, W., Hirano, T., and Fujinuma, Y.: Response of $\mathrm{CO}_{2}$ flux to environmental variables in two larch forest ecosystems in east Asia, Phyton-Ann. Rei. Bot. A, 45, 339-346, 2005 b.

Webb, R. S., Rosenzweig, C. E., and Levine, E.R.: Specifying land surface characteristics in general circulation models: soil profile data set and derived water-holding capacities, Global Biogeochem. Cy., 7, 97-108, 1993.

Welp, L. R., Randerson, J. T., and Liu, H. P.: The sensitivity of carbon fluxes to spring warming and summer drought depends on plant functional type in boreal forest ecosystems, Agr. Forest Meteorol., 147, 172-185, 2007.

White, M. A., Thornton, P. E., and Running, S. W.: A continental phenology model fore monitoring vegetation responses to interannual climatic variability, Global Biogeochem. Cy., 11, 217234, 1997.

White, M. A., Thornton, P. E., Running, S. W., and Nemani, R. R.: Parameterization and sensitivity analysis of the BIOME-BGC terrestrial ecosystem model: Net primary production controls, Earth Interactions, 4, 1-85, 2000.

Wilson, K. B., Baldocchi, D. D., and Hanson, P. J.: Spatial and seasonal variability of photosynthetic parameters and their relationship to leaf nitrogen in a deciduous forest, Tree Physiol., 20, 565-578, 2000.

Wilson, K., Goldstein, A., Falge, E., Aubinet, M., Baldocchi, D., Berbigier, P., Bernhofer, C., Ceulemans, R., Dolman, H., Field, C., Grelle, A., Ibrom, A., Law, B. E., Kowalski, A., Meyers, T., Moncrieff, J., Monson, R., Oechel, W., Tenhunen, J., Valentini, R., and Verma, S.: Energy balance closure at FLUXNET sites, Agr. Forest Meteorol., 113, 223-243, 2002.

Zhang, Y., Rossow, W., Lacis, A. A., Oinas, V., and Mishchenko, M.: Calculation of radiative fluxes from the surface to top of atmosphere based on ISCCP and other global data sets: refinements of the radiative transfer model and the input data, J. Geophys. Res., 112, D19105, doi:10.1029/2003JD004457, 2004.

Zober, L.: A World Soil File for Global Climate Modeling, NASA Technical Memorandum 87802, NASA, 33 pp., 1986. 